Arkivoc

Archive for

Organic Chemistry
The Free Internet Journal

for Organic Chemistry
Account

Arkivoc 2018, part vi, 204-233

\title{
Oxidative allene amination for the synthesis of nitrogen-containing heterocycles
}

\author{
Josephine Eshon, Nels C. Gerstner, and Jennifer M. Schomaker* \\ Department of Chemistry, University of Wisconsin, 1101 University Avenue, Madison, WI 53706, USA \\ Email: schomakerj@chem.wisc.edu
}

Received 06-21-2018

Accepted 09-09-2018

Published on line 11-26-2018

\section{Abstract}

The prevalence of stereochemically complex amines in natural products, pharmaceuticals and other bioactive compounds, coupled with the challenges inherent in their preparation, has inspired work to develop new and versatile methodologies for the synthesis of amine-containing stereotriads ('triads'). The key step is a highly chemo-, regio-, and stereo-selective transition-metal catalyzed nitrene transfer reaction that transforms one of the cumulated double bonds of an allene precursor into a bicyclic methyleneaziridine intermediate. This account summarizes our strategies for elaboration of such intermediates into stereochemically rich, densely functionalized amine triads, nitrogen heterocycles, aminated carbocycles and other useful synthetic building blocks.

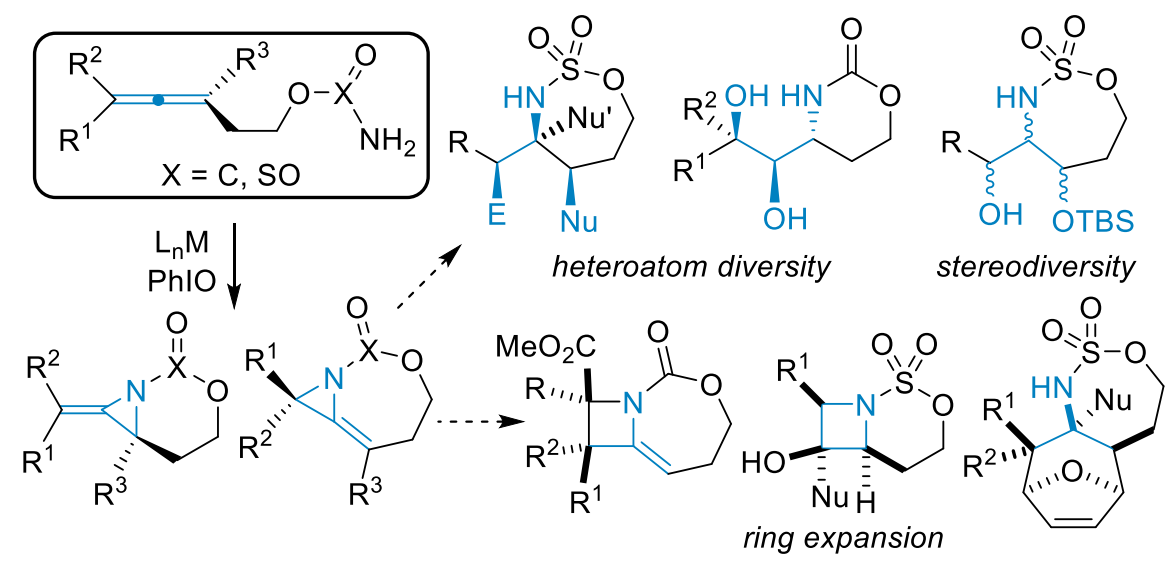

Keywords: Allene, nitrene transfer, amine, axial chirality, methyleneaziridine, azetidine 


\section{Table of Contents}

1. Introduction

1.1 Key features of chiral allenes enabling stereoselective syntheses of amine triads

2. Methods for Transition Metal-catalyzed Allene Aziridination

2.1 Exocyclic methyleneaziridines (MA) from sulfamate nitrene precursors

2.2 Endocyclic methyleneaziridines (MA) from sulfamate nitrene precursors

2.3 Exocyclic methyleneaziridines (MA) from carbamate nitrene precursors

3. Strategies for the Synthesis of Heterocycles from Oxidative Allene Amination

3.1 Tandem allene aziridination/nucleophilic ring-opening

3.2 Treatment of MA with electrophilic reagents

3.3 Ring-expansion strategies

3.4 Formation and trapping of 2-amidoallyl cation intermediates

4. Applications to the Synthesis of Complex Molecules

4.1 Synthesis of aminosugars

4.2 Synthesis of unusual and unnatural amino acids, and fluorinated pyrrolidines

4.2.1 Total synthesis of ( \pm )-detoxinine, its methyl ester, and stereoisomers

4.2.2 Fluorinated pyrrolidines and unnatural amino acids

\subsection{Synthesis of the core of jogyamycin}

5. Concluding Remarks

Acknowledgements

References

\section{Introduction}

Stereochemically complex, densely functionalized amine-containing stereotriads ('triads') are a recurring theme in a host of natural products, bioactive molecules and pharmaceuticals. ${ }^{1-12}$ However, the preparation of amines containing three or more contiguous, heteroatom-bearing stereocenters can be challenging using conventional oxidations of functionalized alkenes, including dihydroxylation and aminohydroxylation, ${ }^{13-18}$ diamination, ${ }^{19-24}$ asymmetric aziridination/ring-opening, ${ }^{25-34}$ or other difunctionalizations, ${ }^{35,36}$ as issues with control over the regio- and/or stereoselectivity often arise. An attractive alternative strategy involves transforming each of the unsaturated carbons of a chiral allene to a new $s p^{3}$ stereocenter, where the resultant triads map onto diverse amine motifs found in an array of biologically significant molecules (selected examples, Figure 1).

Despite the potential of allenes as convenient three-carbon synthons for the preparation of saturated stereotriads, they have been traditionally underutilized in this context. ${ }^{37-44}$ However, we felt that their ready accessibility from well-established reactions, the rapid increase in recent methods for their enantioselective syntheses, and their unique axial chirality, make them ideally suited for this purpose. Our group has been engaged in efforts to rapidly elaborate chiral allenes into densely functionalized and stereochemically complex amine triads via oxidative allene amination strategies. In this review, we describe a suite of methods to introduce heteroatoms into allenes through a highly chemo-, regio-, and stereo-selective allene aziridination reaction. Key features of our chemistry include versatility in the position of the $\mathrm{C}-\mathrm{N}$ bond in the resulting triad, flexibility in the identity of the remaining two carbon-heteroatom bonds, stereochemical diversity, and effective transfer of axial-to-point chirality to furnish enantioenriched amines. 


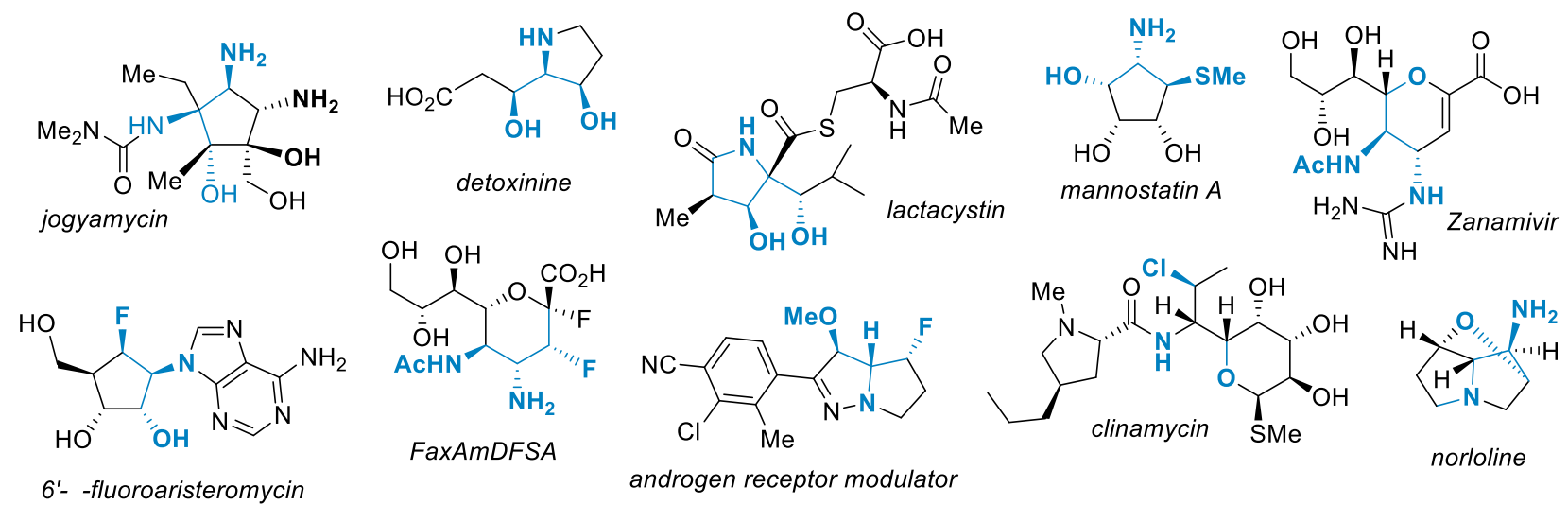

Figure 1. Selected bioactive molecules containing amine 'triads'.

\subsection{Key features of chiral allenes enabling stereoselective syntheses of amine triads}

Chiral allenes contain unique structural features poised to enable the tunable introduction of three new heteroatoms at each site of unsaturation (Scheme 1). For example, many allenes display axial chirality that is readily transferred to point chirality in the products with high fidelity. ${ }^{45-50}$ Allenes are more stereochemically flexible than their alkene counterparts, as a single allene can be selectively transformed into multiple stereoisomeric products. Finally, allenes offer the potential for the controlled introduction of an array of heteroatoms into the triad in a versatile manner.

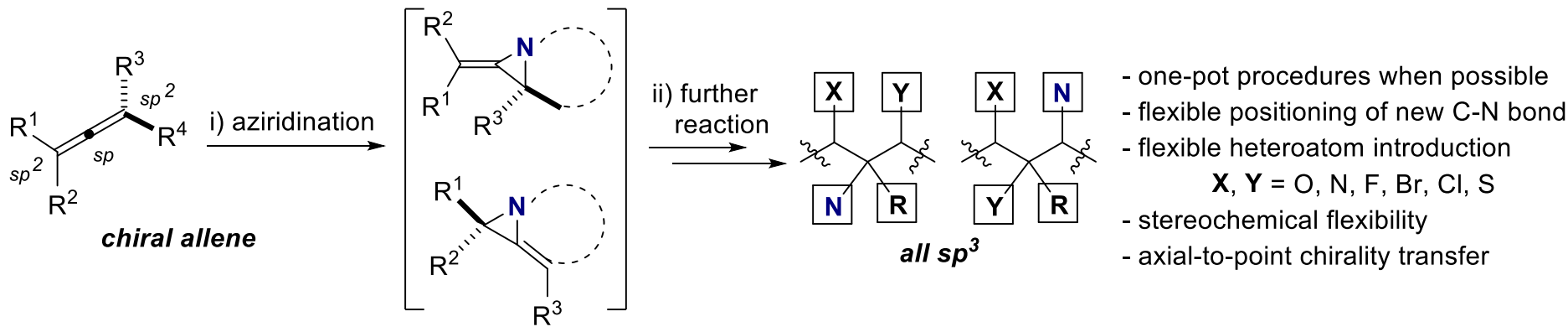

key methyleneaziridine (MA) intermediates

Scheme 1. Goals for transition metal-catalyzed oxidative allene amination.

The key to harnessing the power of the allene synthon to deliver amine triads hinges on exploiting a chemo, regio-, and stereoselective aziridination that generates reactive, strained methyleneaziridine (MA) intermediates (Scheme 1). Depending on the regioselectivity, two MA intermediates are possible, both of which display remarkable versatility in subsequent transformations to deliver acyclic and heterocyclic amines. In this review, we discuss several strategies to transform allenes to amine triad building blocks through the intermediacy of MAs, as well as applications of this chemistry to the preparation of bioactive molecules and the exploration of novel amine chemical space.

\section{Methods for Transition Metal-catalyzed Allene Aziridination}

\subsection{Exocyclic bicyclic methyleneaziridines (MA) from sulfamate nitrene precursors}

The first challenge in developing oxidative allene amination methodologies was to identify robust methods to achieve chemo-, regio- and stereoselective allene aziridination. Based on literature precedent and our initial 
investigations, controlling the regioselectivity of intermolecular allene aziridination was difficult and often led to unstable products. ${ }^{51-53}$ In contrast, intramolecular aziridination of homoallenic sulfamates of the form 1 (Scheme 2) using a dinuclear $\mathrm{Rh}(\mathrm{II})$ catalyst, such as $\mathrm{Rh}_{2}(\mathrm{TPA})_{4}$ (TPA = triphenylacetate), yielded exocyclic methyleneaziridines of the form 2 with excellent chemo-, regio-, and stereoselectivity. ${ }^{54-56}$ While the labile 2 could be observed by NMR, it was readily opened in the presence of water or silica gel. Therefore, the aziridination was followed by immediate ring-opening to afford the enesulfamate $\mathbf{3}$ in good yield and excellent stereoselectivity in favor of the $E$ isomer. ${ }^{54}$
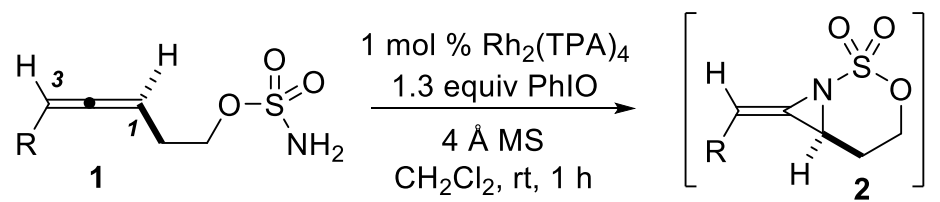

$E$ isomer is the major product
methyleneaziridine is not isolable
no competing $\mathrm{C}-\mathrm{H}$ insertion
aziridination of the proximal double bond

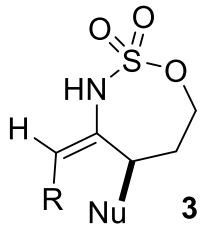

Scheme 2. Rh(II)-catalyzed aziridination of homoallenic sulfamates to bicyclic methyleneaziridines.

A variety of substitution patterns on 1 were tolerated, including 1,3-dialkyl-, 3-aryl-, and 1,1',3-trialkylsubstituted allenes. The nucleophile scope encompassed carboxylic acids, alcohols, thiols, halides and amines (Scheme 6, vide infra). The axial chirality of enantioenriched 1 was transferred to the enesulfamate products 3 with $>95 \%$ fidelity. ${ }^{54}$

\subsection{Endocyclic methyleneaziridines (MA) from sulfamate nitrene precursors}

Reaction at the distal C2-C3 double bond of 4a-c (Scheme 3) to generate endocyclic methyleneaziridines was achieved by installing a silyl group at $\mathrm{C} 1$ of the allene. ${ }^{57}$ The electronic effect exerted by the trialkylsilyl group stabilizes the developing positive charge on the $\beta$ carbon in the transition state through hyperconjugative interaction with the $\mathrm{C}-\mathrm{Si}$ bond that is coplanar with the distal $\pi$ orbitals, leading to $\mathbf{5 c}$. Monoalkyl substitution on C3 was well-tolerated in this chemistry, as was alkyl substitution in the tether between the allene and the sulfamate; however, 1,1',3,3'-tetrasubstituted allenes gave only elimination products. In contrast to the exocyclic MAs described in Section 2.1, endocyclic MAs were stable to column chromatography and could be readily isolated.

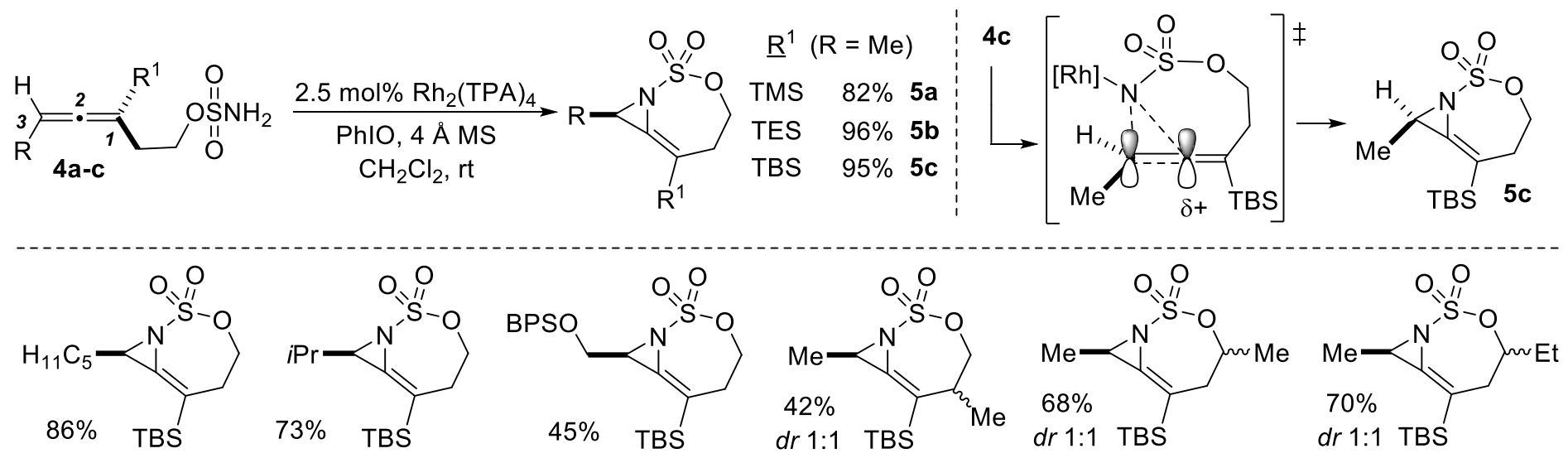

Scheme 3. Electronic control over the regioselectivity of allene aziridination at the C2-C3 bond. 


\subsection{Exocyclic methyleneaziridines (MA) from carbamate nitrene precursors}

To expand the versatility of oxidative allene amination, homoallenic carbamates of the form $\mathbf{6}$ were explored in intramolecular allene aziridination (Scheme 4). In contrast to sulfamates, carbamates gave mixtures of $E: Z$ isomers of 7, as well as competing $\mathrm{C}-\mathrm{H}$ bond amidation to $8 .^{58,59}$ The use of the $\mathrm{Rh}_{2}(\mathrm{esp})_{2}$ catalyst $\left(\operatorname{esp}=\alpha, \alpha, \alpha^{\prime}, \alpha^{\prime}-\right.$ tetramethyl-1,3-benzenedipropionic acid) and PhlO generally gave poor chemoselectivity for 7 over 8 . Fortunately, we found that AgOTf supported by bipyridine (bipy), 1,10-phenanthroline (phen), or dimethylbisoxazoline (tmbox) ligands resulted in excellent catalyst control over the chemoselectivity of the nitrene transfer event. ${ }^{60-62}$ Approximately equimolar amounts of AgOTf and a phen ligand transformed allenes 6a-c of diverse substitution patterns selectively into MAs 7a-c with moderate-to-good E:Z ratios; the two isomers were easily separated by column chromatography. The carbamoyl-derived MAs were more robust than the analogous sulfamoyl-derived MAs and survived column chromatography with no competing ring-opening.
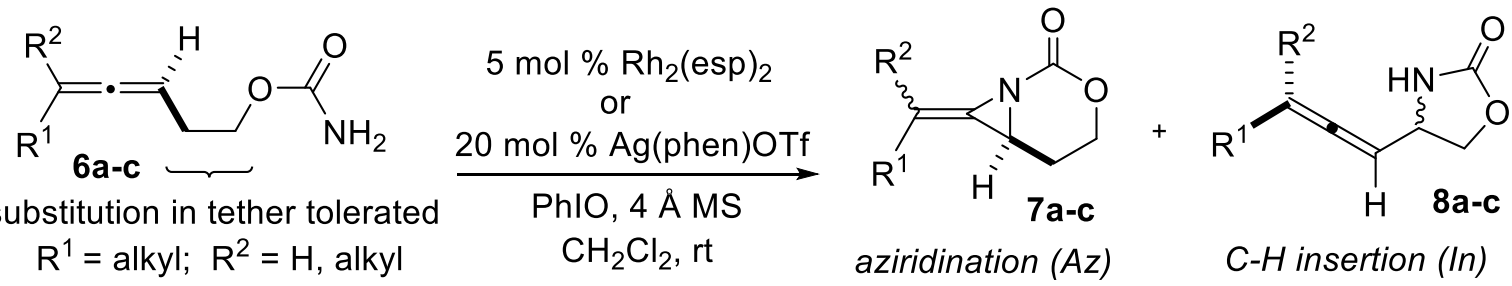

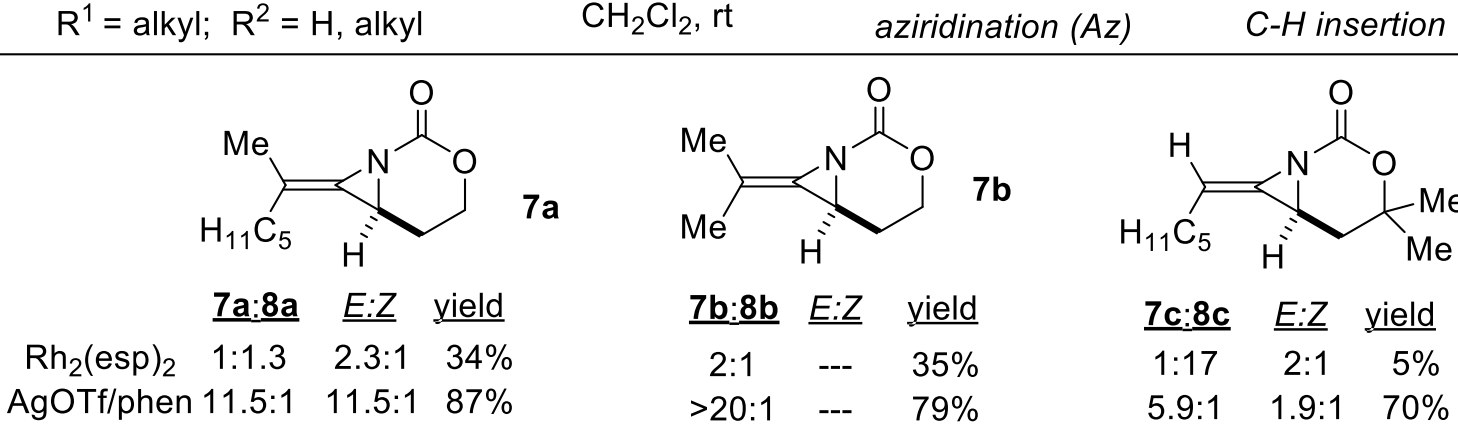

Scheme 4. $\mathrm{Ag}(\mathrm{I})$-catalyzed aziridination of homoallenic carbamates.

\section{Strategies for the Synthesis of Heterocycles from Oxidative Allene Amination}

With methods in hand for chemo-, regio-, and stereo-selective syntheses of bicyclic MAs from allenes, chemistry to exploit their unusual features was explored. Scheme 5 presents a summary of the complex amine scaffolds accessible from 9 through the intermediacy of $\mathbf{1 0}$ and 11. Approaches are divided into four main strategies; Section 3.1 addresses the ring-opening of sulfamoyl-derived aziridines $\mathbf{1 0}$ with an array of nucleophiles ultimately to furnish triads $\mathbf{1 2}$ with stereochemical flexibility at C1-C3. Section 3.2 describes reactions of carbamoyl-derived MAs 10 to furnish aminodiols and diaminoalcohols of the form 13-14. Ring expansion strategies in Section 3.3 enable access to densely substituted azetidines 15 and 17, heterocycles that are challenging to prepare with other synthetic methods. Finally, bicyclic MAs provide a convenient way to access 2-amidoallyl cation intermediates 18, which are under-explored compared to their 2-oxallyl cations; this chemistry is discussed in Section 3.4. 


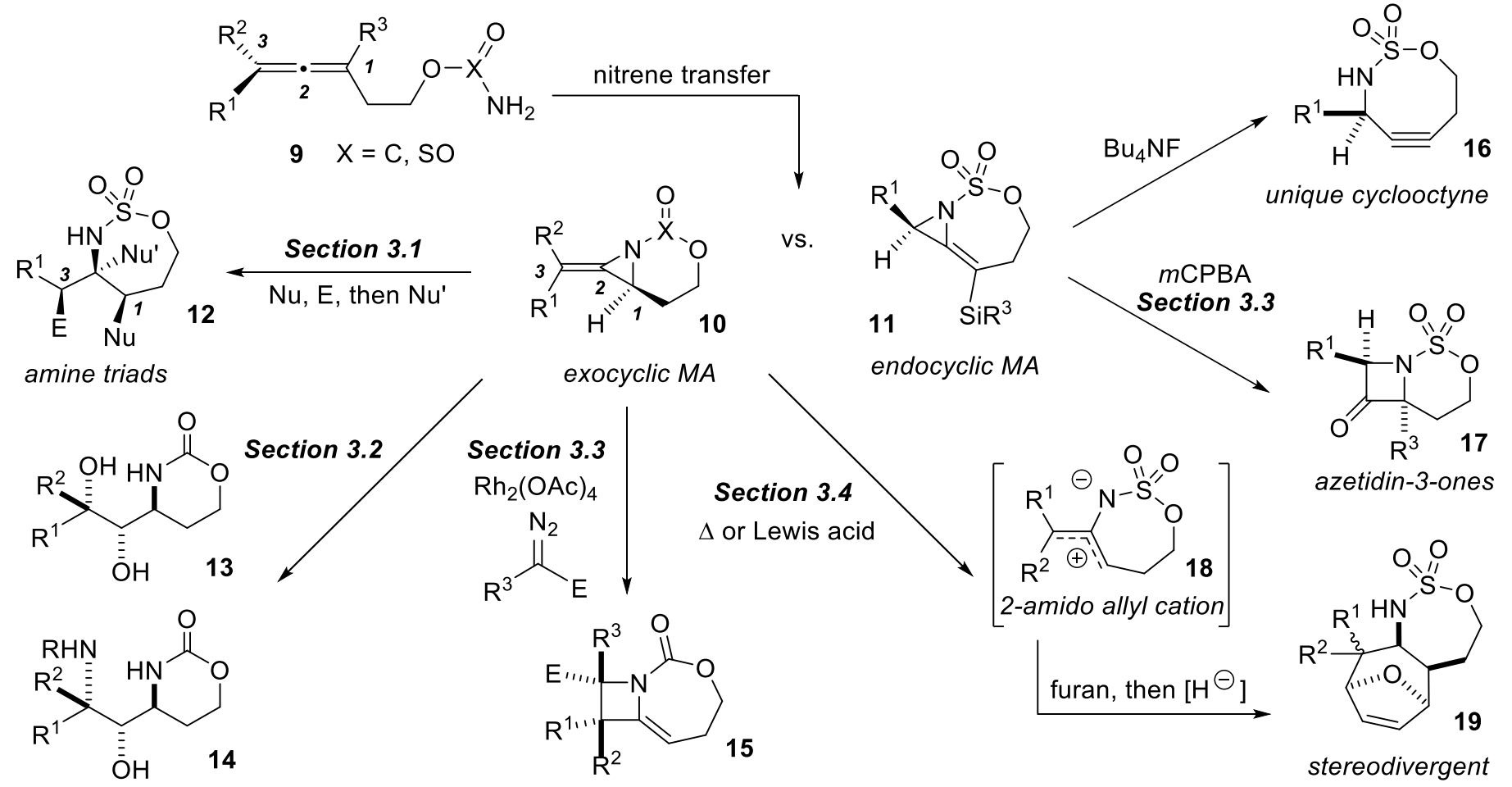

Scheme 5. Summary of oxidative allene amination methods.

\subsection{Tandem allene aziridination/nucleophilic ring-opening}

Two major advantages of utilizing MAs as reactive intermediates are their strain (ca. $42 \mathrm{kcal} / \mathrm{mol})$ and the ability to exquisitely control the regioselectivity of nucleophilic ring-opening. Sulfamoyl-containing MAs are not isolable, but their high reactivity enables a convenient one-pot process to convert allenes to triads bearing contiguous, stereodefined $\mathrm{C}\left(s p^{3}\right)-\mathrm{X}$ or $\mathrm{C}\left(s p^{3}\right)-\mathrm{C}$ bonds. ${ }^{54}$ Selected scope for the four-step, one-pot process is shown in Scheme 6 and entails: 1) aziridination of 20,2) in situ ring-opening of 21, 3) electrophilic substitution of the resulting enesulfamate $\mathbf{2 2}$ to furnish 23, and 4) a final imine reduction to furnish $\mathbf{2 4}$. The ring strain and leaving group ability of the sulfamoyl group in $\mathbf{2 1}$ enabled diverse nucleophiles, including alcohols, carboxylic acids, amines, thiols, halides and water, to open the aziridine at rt. The resulting enesulfamates $\mathbf{2 2}$ reacted with a variety of electrophiles to introduce halogen, oxygen, sulfur, and nitrogen groups at C3 of the original allene. Imine 23 could be reduced with hydride, cyanide, or Grignard nucleophiles to give triad 24. The 1,2-syn:2,3-syn diastereomer was typically the major product, due to the conformations adopted by $\mathbf{2 2}$ and $\mathbf{2 3}$ to minimize $A^{1,3}$ strain. The heteroatoms flanking the C2 amine could be tuned to give a diverse array of triads in good $d r$, including 25-29. Importantly, efficient axial-to-point chirality transfer from the allene precursor to the triad was noted for 30.

The presence of fluorine in drugs often leads to improved pharmacological properties; indeed, $\mathrm{C}\left(s p^{3}\right)-\mathrm{F}$ bonds are embedded in aminated triads that occur in anti-virals, neuraminidase inhibitors and modulators of androgen receptors (Figure 1, vide infra). ${ }^{63-70}$ Oxidative allene amination provides convenient access to fluorinated triads in good-to-excellent $d r$ (Scheme 7) ${ }^{71}$ via reaction of 32 with Selectfluor ${ }^{R}{ }^{72}$ followed by reduction with hydride, Grignard or cyanide nucleophiles to furnish 34-44 in moderate-to-excellent $d r$. Our ability to install fluorine at quaternary carbons in 37-42 was particularly noteworthy, as this is challenging to achieve via fluoride ring-openings of typical epoxides or aziridines. 
General strateqv

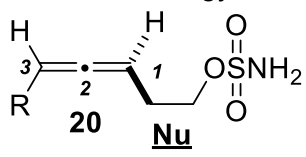

$\mathrm{AcOH}, \mathrm{MeOH}, \mathrm{H}_{2} \mathrm{O}$

TMSCl, $\mathrm{PhSH}, \mathrm{PhNH}_{2}$

$\mathrm{R}_{2} \mathrm{NH}, \mathrm{HF}^{*} \mathrm{Et}_{3} \mathrm{~N}$
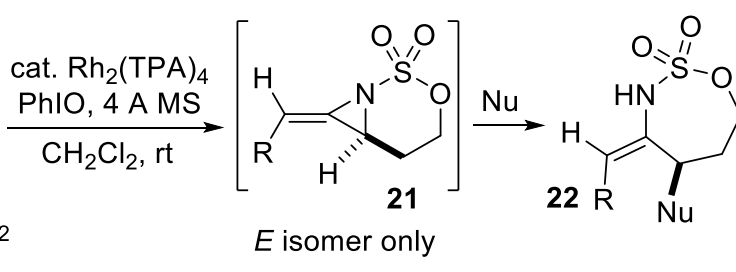
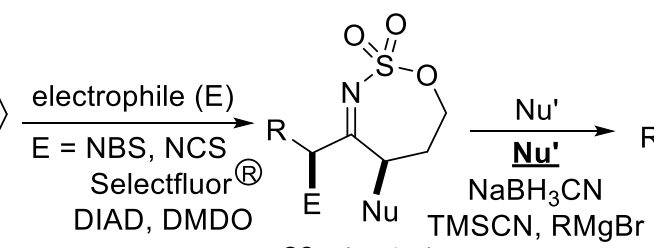
23a (major)

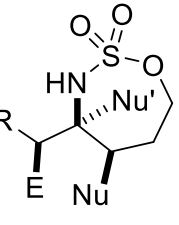

24 (major)

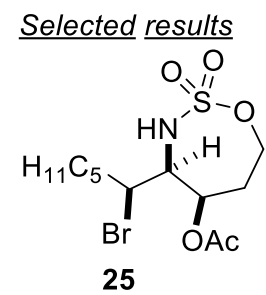

$61 \%, 20: 1 d r$

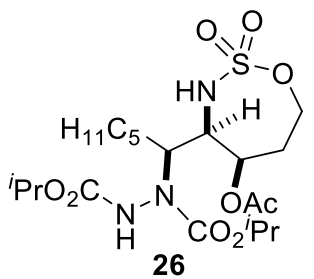

$69 \%, 20: 1 d r$

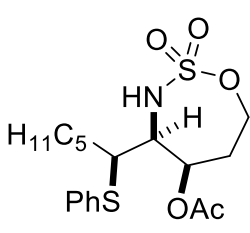

27

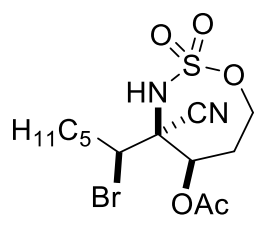

28

$73 \%, 3.3: 1 d r$

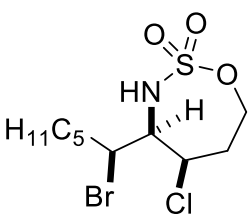

29

$77 \%, 20: 1 d r$

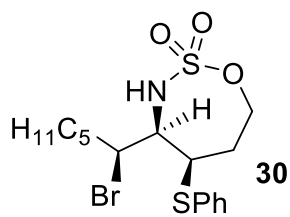

allene, $99 \%$ ee $61 \%, 15: 1$ dr $99 \%$ ee

Scheme 6. Selected scope of ring-opening of sulfamoyl-derived methyleneaziridines to aminated stereotriads.

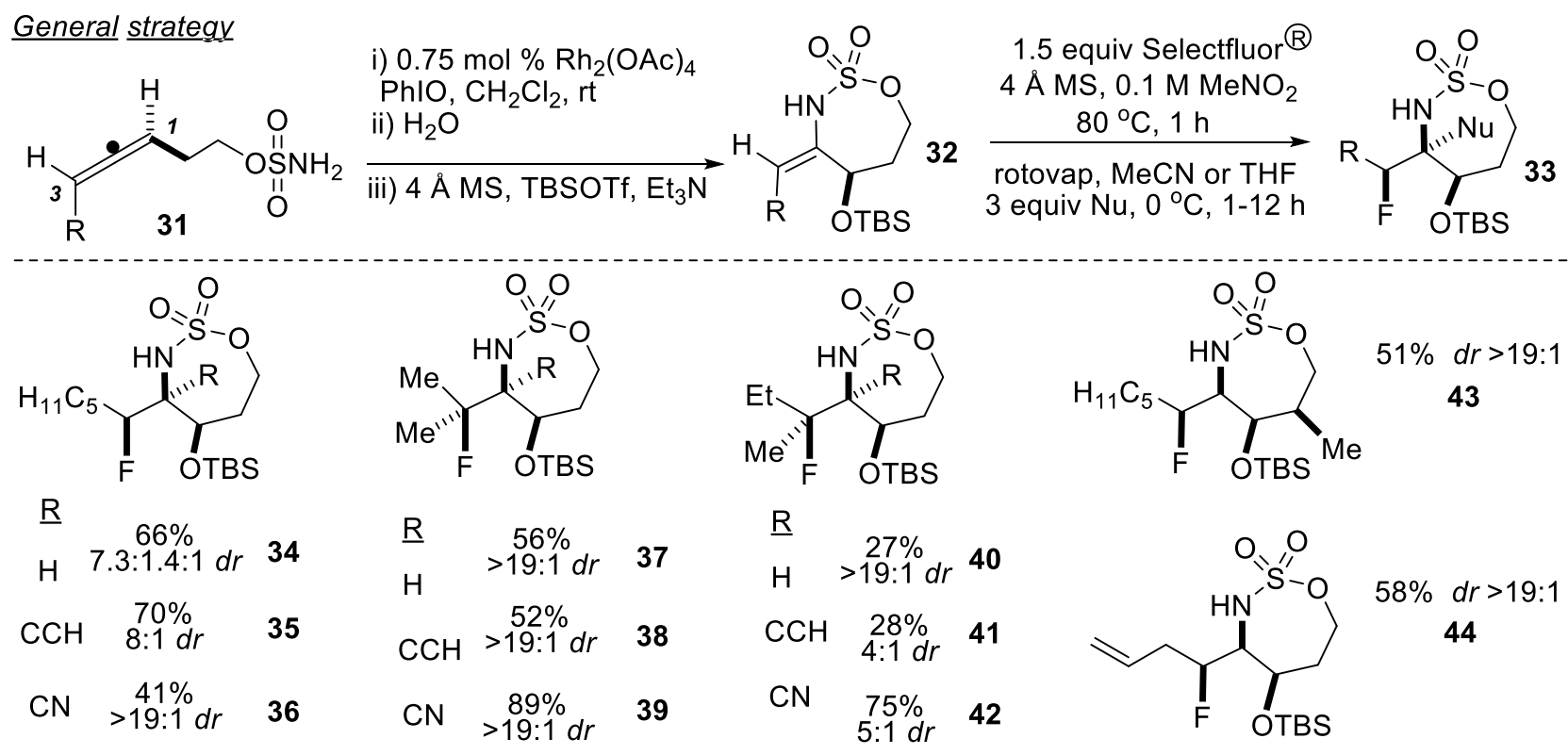

Scheme 7. Introduction of fluorine into all-syn amine stereotriads.

In addition to flexibility in the identity of the heteroatoms that can be introduced into amine triads, oxidative allene amination offers the potential for stereochemical versatility. For example, stereodivergent syntheses of $\mathrm{O} / \mathrm{N} / \mathrm{O}$ triads from single allene precursors has been achieved. ${ }^{73}$ The general strategy is shown in Scheme $8 \mathrm{~A}$, where a single enantioenriched allene $\mathbf{4 5}$ can be converted to any one of the four possible diastereo- and enantioenriched amine triads 49, 52, 53, and 56.

The stereodivergent oxidative allene amination begins with a one-pot transformation of $\mathbf{4 5}$ to $\mathbf{4 7}$, where a bulky OTBS group at $\mathrm{C} 1$ ensures good $d r$ in the subsequent addition of $\mathbf{4 7}$ to dimethyldioxirane (DMDO) to give 1,3-anti-48, presumably via a concerted addition displaying an early transition state. The oxidation event can be telescoped with the reduction using $\mathrm{Zn}\left(\mathrm{BH}_{4}\right)_{2}$ to yield the 1,2-syn:2,3-anti triad 49. Yields over the two steps are in the range of $80-84 \%$ (Scheme $8 \mathrm{~B}$, left) with moderate-to-good $d r$. Access to the remaining diastereomers requires isomerization of $(E)-\mathbf{4 7}$ to (Z)-50, which is achieved in near-stoichiometric yield using a one-pot addition/elimination sequence. Conversion of $\mathbf{5 0}$ to the 1,2-anti:2,3-anti triad $\mathbf{5 3}$ proceeds in a similar fashion 
to that described for reaction of 47. Selected scope is illustrated in Scheme 8B, right-hand table, furnishing 62$90 \%$ yields of the triads over the two steps with good $d r$. The reader is referred to the original reference for the scope of the remaining two triads 52 and $56 .^{73}$
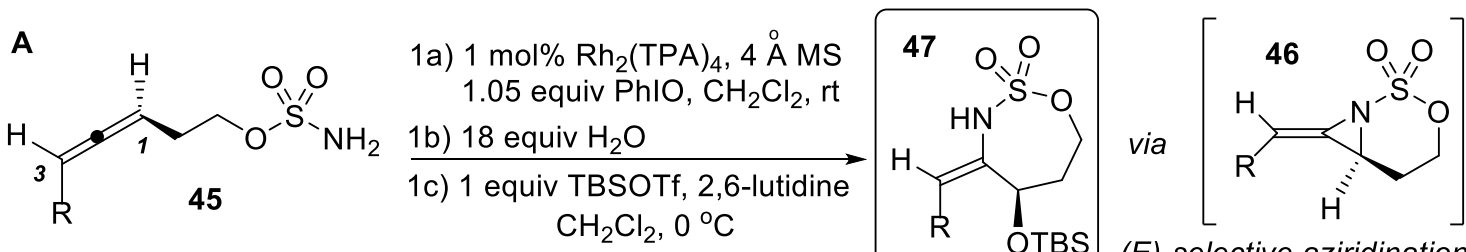<smiles>[R]C=C1NS(=O)(=O)OCC[C@@H]1[OH2+]</smiles>

1a) 1.05 equiv NBS, THF, $0{ }^{\circ} \mathrm{C}$

(E)-selective aziridination

1b) 2.0 equiv $\mathrm{ZnEt}_{2}$

1c) $\mathrm{NH}_{4} \mathrm{Cl}$ quench

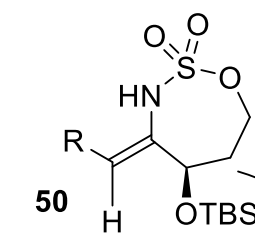

complete $Z$ selectivity

DMDO, $\mathrm{CH}_{2} \mathrm{Cl}_{2}, 0^{\circ} \mathrm{C}$<smiles>[R]C(O)C1=NS(=O)(=O)OCC[C@H]1[OH+]</smiles><smiles>[R]C(=O)[C@H]1NS(=O)(=O)OCC[C@H]([O+])[C@@H]1C([R])=O</smiles>

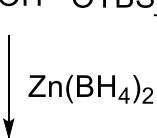

$\left(\mathrm{Me}_{4} \mathrm{~N}\right) \mathrm{BH}(\mathrm{OAc})_{3}$ 1:1 AcOH:MeCN
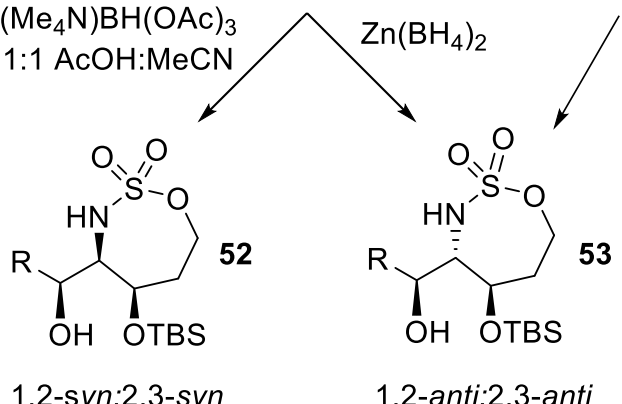

$\mathrm{NaBH}_{4}, \mathrm{MeOH}$

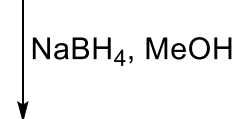<smiles>[R]C(O)[C@H]1NS(=O)(=O)OCCC1([R5])[R5]</smiles>

1,2-syn:2,3-syn

1,2-anti:2,3-anti<smiles></smiles>

B

$\mathrm{O}, 11$

1a) 2 equiv DMDO

OTBS

1b) reductant<smiles></smiles>

1,2-syn:2,3-ant

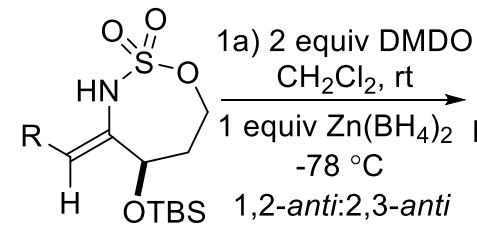

1,2-anti:2,3-syn

\begin{tabular}{ccccr}
\hline entry $^{a, b}$ & $\mathrm{R}$ & $\mathrm{R}^{\prime}$ & yield & \multicolumn{1}{c}{$d r$} \\
\hline 1 & ${ }^{i} \mathrm{Pr}$ & $\mathrm{H}$ & $80 \%$ & $>9: 1$ \\
2 & ${ }^{i} \mathrm{Pr}$ & $\mathrm{Ph}$ & $84 \%$ & $>9: 1$ \\
3 & ${ }^{i} \mathrm{Pr}$ & $\mathrm{CHCH}_{2}$ & $83 \%$ & $8.2: 1$ \\
4 & ${ }^{i} \mathrm{Pr}$ & $\mathrm{CCH}$ & $81 \%$ & $7.4: 1$ \\
5 & $\mathrm{C}_{5} \mathrm{H}_{11}$ & $\mathrm{H}$ & $82 \%$ & $5: 1$ \\
\hline
\end{tabular}

${ }^{a}$ entries 1, 5: 1 equiv $\mathrm{Zn}\left(\mathrm{BH}_{4}\right)_{2},-78{ }^{\circ} \mathrm{C}$.

${ }^{b}$ entries 2-4: 3.0 equiv Grignard reagent.

Scheme 8. Stereochemical diversity in oxidative allene amination.

\subsection{Treatment of MA with electrophilic reagents}


An alternative mode of reactivity of bicyclic MA intermediates involves functionalizing the exocyclic alkene prior to aziridine ring-opening. In this context, a carbamate nitrene precursor was necessary to ensure that the MA 57 was stable and isolable. The bicyclic ring renders electrophilic transformations of the alkene highly diastereoselective. For example, treatment of MAs of the form 57 (Scheme 9) with $\mathrm{N}$-aminophthalimide $\left(\mathrm{PhthNNH}_{2}\right)$ in the presence of PhIO resulted in complete facial selectivity to give tricyclic 1,4-diazaspiro[2.2]pentanes 58 (DASPs) in >19:1 dr. Monoalkyl substitution ${ }^{58}$ at C3 of the MA furnished 59-62 in good yields. The substitution pattern of the original allene, and hence the MA, could be varied to furnish DASPs 62-63 in good-to-moderate yields. One important feature of this 'intra/intermolecular' aziridination strategy is that the two rings of the DASP are electronically differentiated; the bicyclic aziridine contains an electron-withdrawing group, while the spiro ring bears an electron-donating group. Methods to selectively open either of these rings have been reported by our group; however, the difficulty of cleaving the $\mathrm{N}-\mathrm{N}$ bond of the protecting group limits the utility of DASPs in this context. ${ }^{58}$
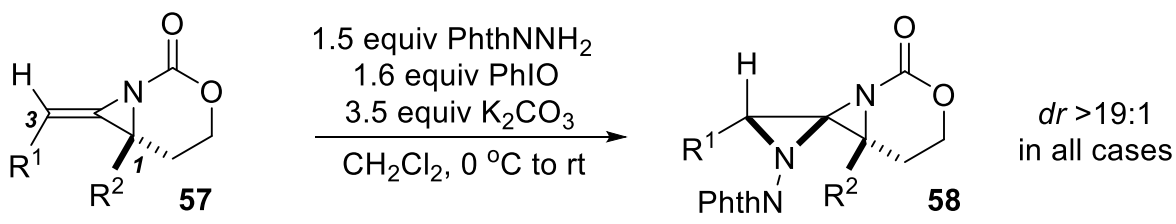

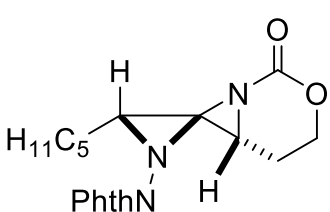

$58 \% \quad 59$

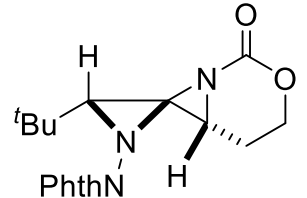

$79 \% \quad 60$

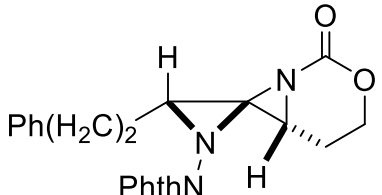

$75 \% \quad 61$

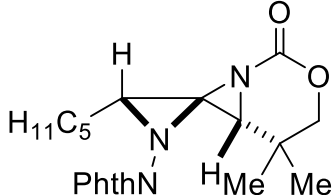

$72 \% \quad 62$

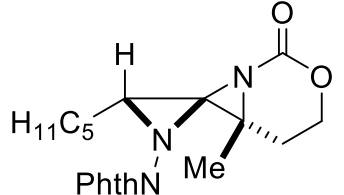

$46 \% \quad 63$

Scheme 9. Intermolecular aziridination of methyleneaziridines to 1,4-diazaspiro[2.2]pentanes.

An alternative strategy to functionalize 64 via $\mathbf{6 5}$ (Scheme 10) involves a $\mathrm{RuCl}_{3}$-catalyzed dihydroxylation to yield 1-amino-2,3-diols of the form $66 .^{74}$ The substitution pattern of 64 dictates the optimal conditions for the

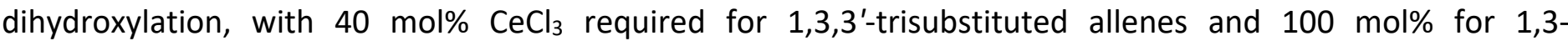
disubstituted precursors. Subsequent reduction with $\mathrm{NaBH}_{4}$ furnished 67-70. Removal of the gem-dimethyl group in the carbamate ring of 65 required a switch in additive from $\mathrm{CeCl}_{3}$ to $\mathrm{H}_{2} \mathrm{SO}_{4}$ to prevent competitive aziridine ring-opening, as well as the use of $\mathrm{Zn}\left(\mathrm{BH}_{4}\right)_{2}$ as the reducing agent to give the 1,2-anti:2,3-syn aminodiols 71-73.

Aminohydroxylation of carbamoyl-derived MA 74 furnished 1,3-diamino-2-ols 76 in good dr, provided a gem-dimethyl group was present in the precursor (Scheme 11). ${ }^{75}$ The initial oxidation event gave direct access to the 1,3-diaminoketone products 77-82, with the exocyclic nitrogen protected with an easily cleaved sulfonyl or Boc group. Selective reduction was achieved using $\mathrm{NaBH}_{4}$ in either $\mathrm{CH}_{2} \mathrm{Cl}_{2}$ or a $1: 1$ mixture of $\mathrm{CHCl}_{3}: \mathrm{H}_{2} \mathrm{O}$ to give 77a-82a. The process was general for a variety of alkyl- and aryl-substituted MAs derived from 1,3disubstituted allenes, although the identity of the chloramine was crucial to obtain good yields. For example, sulfonamides (Conditions A-B) worked best for alkyl-substituted allenes, while BocNNaCl was a better nitrogen source when the allene was aryl-substituted. In contrast to the dihydroxylation of MAs, 1,3,3'-trisubstituted MAs were not tolerated and the gem-dimethyl group was critical for good $d r$ in the reduction. 


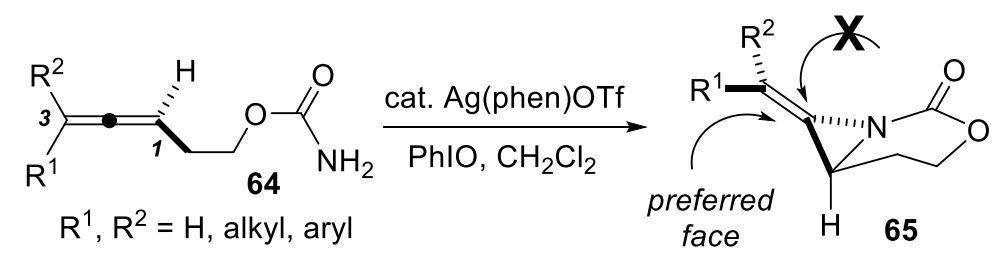

1) $1 \mathrm{~mol} \% \mathrm{RuCl}_{3}, 1.5$ equiv $\mathrm{NalO}_{4}$ $40-100 \mathrm{~mol} \% \mathrm{CeCl}_{3}$ or $20 \mathrm{~mol}_{2} \mathrm{H}_{2} \mathrm{SO}_{4}$ 2:1 MeCN: $\mathrm{H}_{2} \mathrm{O}$ or 3:3:1 EtOAc:MeCN: $\mathrm{H}_{2} \mathrm{O}$

2) $\mathrm{NaBH}_{4}$ or $\mathrm{Zn}\left(\mathrm{BH}_{4}\right)_{2}$<smiles>[R]C([R])(O)[C@@H](O)[C@H]1CCOC(=O)N1</smiles><smiles>CC(C)C[C@](C)(O)[C@H](O)[C@H]1NC(=O)OC[C@]1(C)CC(C)(O)[C@@](C)(O)[C@@H](O)[C@H]1NC(=O)OCC1(C)C</smiles>
$94 \% d r>19: 167 \quad 74 \% d r>19: 168 \quad 74 \% d r>19: 169 \quad 66 \% d r 7.9: 170$ from $E-65$ from Z-65<smiles>C[C@@](O)([18OH])[C@@H](O)[C@@H]1CCOC(=O)N1</smiles>

$79 \%$ dr 5.7:1 71<smiles>CCCCCCS[C@@](C)(O)[C@@H](O)C1CC(C)(C)OC(=O)N1</smiles>

$80 \% d r 6.6: 172$<smiles>O=C1NC([C@H](O)C(O)(P)P)CCO1</smiles>

$86 \% d r 6.1: 173$

Scheme 10. Stereocontrolled dihydroxylation of MA to furnish 1-amino-2,3-diols.<smiles>[R]C([R])=C1[C@@H]2N1C(=O)OCC2(C)C</smiles>

1) aminohydroxylation

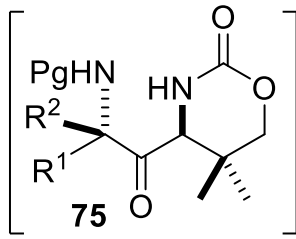

2) reduction<smiles>[R]C([R])(N)[C@@]([R])(N)C(O)[C@H]1NC(=O)OCC1(C)C</smiles><smiles>CC1(C)COC(=O)NC1C(O)[C@@H]([13CH3])N</smiles>

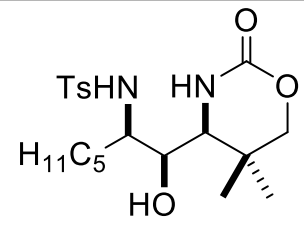

A $7779 \%$

77a $83 \%$ dr 10:1
A $7860 \%$
78a $83 \%$ dr 10:1<smiles>CC(C)(C)OC(=O)[C@@H](NC1NC(=O)OCC1(C)C)C(O)[PH2]c1ccccc1</smiles><smiles>[R]C(N[B])[C@@H](O)[C@H]1NC(=O)OCC1(C)C</smiles>

dr 10:1

in all cases
C $7955 \%$
79a $88 \% d r>19: 1$

\begin{tabular}{llll}
${ }^{i} \mathrm{Bu}, \mathrm{H}$ & B & $\mathbf{8 0} 57 \%$ & $\mathbf{8 0 a} 94 \%$ \\
TIPSO $\left(\mathrm{CH}_{2}\right)_{2}, \mathrm{H}$ & $\mathbf{B}$ & $\mathbf{8 1 5 5 \%}$ & $\mathbf{8 1 a} 94 \%$ \\
$\mathrm{Ph}\left(\mathrm{CH}_{2}\right)_{2}, \mathrm{H}$ & B & $\mathbf{8 2} 57 \%$ & $\mathbf{8 2 a} 88 \%$ \\
\hline
\end{tabular}

A: Aminohydroxylation: $7.5 \mathrm{~mol} \% \mathrm{~K}_{2} \mathrm{OsO}_{2}(\mathrm{OH})_{4}$, Chloramine T, $33^{\circ} \mathrm{C}$. Reduction: $\mathrm{NaBH}_{4}$ in $\mathrm{CH}_{2} \mathrm{Cl}_{2}$, rt.

B: Aminohydroxylation: $10 \mathrm{~mol} \% \mathrm{OsO}_{4}$, Chloramine B, $37^{\circ} \mathrm{C}$. Reduction: $\mathrm{NaBH}_{4}$ in $\mathrm{CH}_{2} \mathrm{Cl}_{2}$.

C: Aminohydroxylation: $7.5 \mathrm{~mol} \% \mathrm{OsO}_{4}, \mathrm{BocNNaCl}, 30^{\circ} \mathrm{C}$. Reduction: $\mathrm{NaBH}_{4}$ in $1: 1 \mathrm{CHCl}_{3}: \mathrm{H}_{2} \mathrm{O}$ with sonication.

Scheme 11. Aminohydroxylation/reduction of MA to furnish 1,3-diamino-2-ols. 


\subsection{Ring-expansion strategies}

Azetidines are four-membered saturated nitrogen heterocycles that are of interest for the rigidification of alkylsubstituted amines and for their potential as pharmaceutical candidates. The dearth of methods to prepare densely substituted azetidines with high levels of regio- and stereocontrol have stimulated interest in new synthetic approaches. ${ }^{76-83}$ Ring-expansion reactions of both sulfamoyl- and carbamoyl-derived MAs present a unique opportunity to provide stereocontrolled access to these heterocycles from allene precursors.

Endocyclic MAs are generated via aziridination of the distal allene double bond of a silylated allene $\mathbf{8 3}$ (Schemes 12 and 3, vide supra). ${ }^{57}$ Following formation and purification of the column-stable MA 84, oxidation of the double bond with $m$ CPBA delivered the fused azetidin-3-one 86 in good yield and excellent $d r$.

General strategv
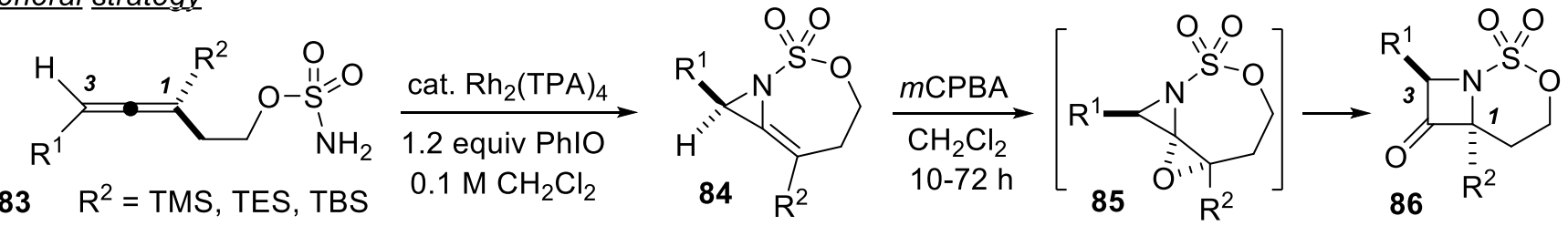

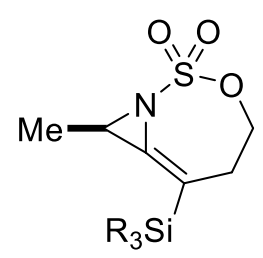

TBS $95 \% 87$

TES $96 \% 88$<smiles>CC(C)C1C2=C(S)CCOS(=O)(=O)N1C2C(C)C</smiles>

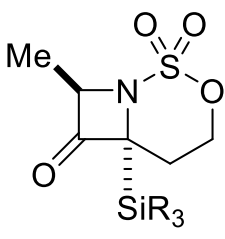

$84 \% d r>19: 187 a$

$63 \% d r>19: 188 a$

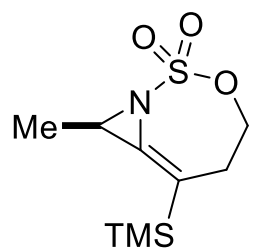

$82 \% 89$

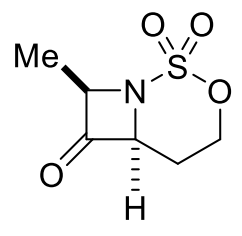

$63 \% d r>19: 189 a$

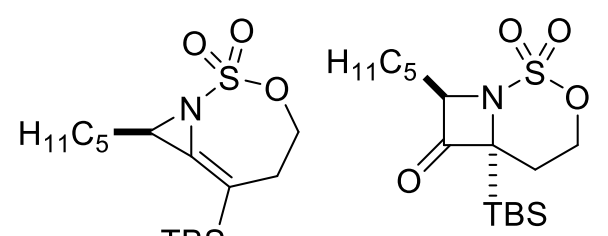

$86 \% 90$

$83 \%$ 90a $d r>19: 1$

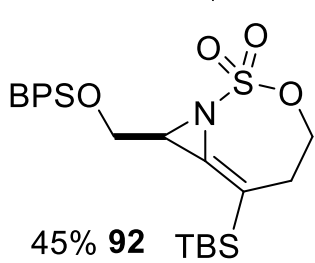

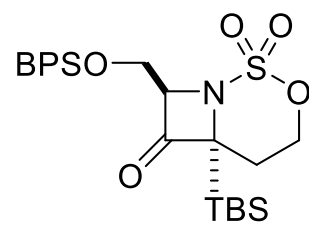

$45 \%(54 \%$ brsm $)$ 92a $d r>19: 1$

Scheme 12. Selected substrate scope of the azetidin-3-one formation from endocyclic MA.

Formation of $\mathbf{8 6}$ was proposed to occur through rearrangement of a transient 1,4-oxaza-[2.2]spiropentane 85, although this intermediate was not observed spectroscopically. In terms of the substrate scope, 1,1',3trisubstituted allenes were well-tolerated to furnish heterocycles 87-92. The size of the silyl group at $\mathrm{R}^{2}$ (TBS vs. TES vs. TMS) did not affect the regioselectivity or the subsequent transformation of the endocyclic MA to the azetidinone, but could be engaged to control subsequent functionalizations of the heterocycle (Scheme 13). When diastereomeric mixtures of allenes were employed, two diastereomeric azetidinones were formed (not shown); these could be readily separated by column chromatography. In all cases, axial-to-point chirality transfer occurred with excellent fidelity to deliver enantioenriched products.

Further manipulations of azetidin-3-ones could be carried out by opening the sulfamate ring of the TBSsubstituted 93 with nucleophiles to give 95-97 (Scheme 13A), where the bulky TBS group blocks the expected reaction at the carbonyl group. In contrast, the use of a TMS group on allenes of the form $\mathbf{8 3}$ leads to desilylation; treatment of the representative azetidin-3-one $\mathbf{9 8}$ gave reaction at the carbonyl group to deliver 99-102 (Scheme 13B). ${ }^{57}$ 


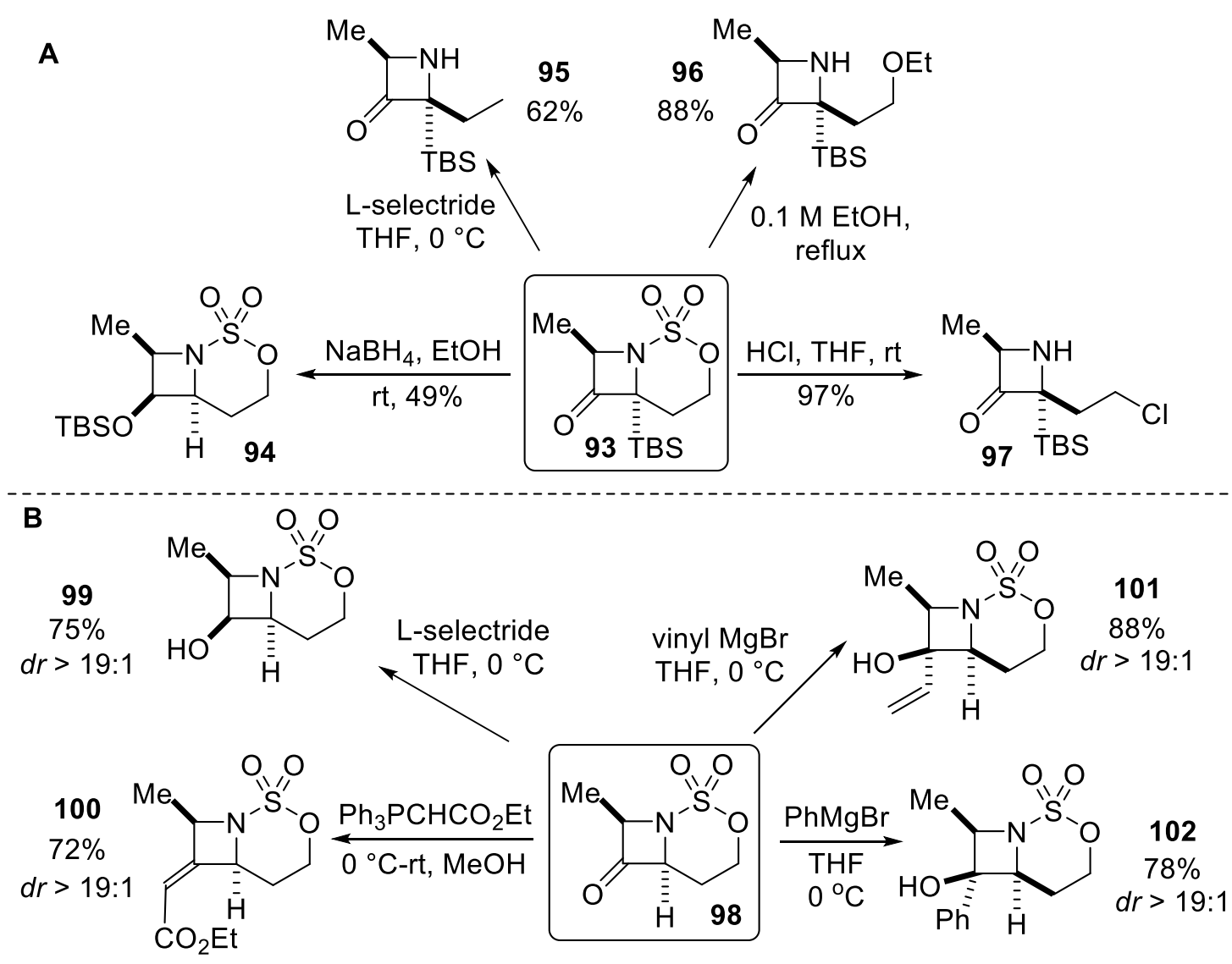

Scheme 13. Further manipulations of azetidin-3-ones controlled by the identity of the silyl group.

Silver-catalyzed aziridination of $\mathbf{1 0 3}$ gives excellent chemoselectivity for the carbamoyl-based MA 104 over competing $\mathrm{C}-\mathrm{H}$ bond amidation (Scheme 14). ${ }^{60-62,84}$ Addition of a $\mathrm{Rh}_{2}(\mathrm{OAc})_{4}$ catalyst and a donor/acceptor carbene precursor 105 results in a stereoselective, one-carbon ring expansion to yield highly substituted methyleneazetidines of the form 106. Phenyl diazoacetate, as well as electron-rich and electron-poor aryl diazoacetates, were successful in the reaction to furnish azetidines 107-111 in 78-92\% yield and $>19: 1 d r .{ }^{84}$ Ortho substitution on the aryl ring of the carbene was tolerated, as were heterocycles represented by 112 . The aryl group of the donor/acceptor carbene precursor could be replaced with an alkyl or vinyl group, as in 113114; alternatively, a styrenyl-based carbene precursor cleanly gave azetidine 115.

Alkyl-substituted E-MA isomers (>10:1 E:Z) were successful in the reaction, delivering 116-117 in good yields and excellent $d r$. While 1,3,3'-trisubstituted allene precursors gave bicyclic MAs that reacted slowly with bulky carbene partners, employing a less-hindered styrenyl diazo precursor gave fully substituted azetidine 118 in $94 \%$ yield. A highlight of the method was the conversion of a 4:1 mixture of $E / Z$ isomers of a chiral MA to 119 in $3: 1$ $d r$ and $89 \%$ yield. The diastereomers were easily separated to give the syn- $\mathrm{Me} / \mathrm{CO}_{2} \mathrm{Me}$ isomer of 119 in $54 \%$ yield and 15:1 $d r$. 


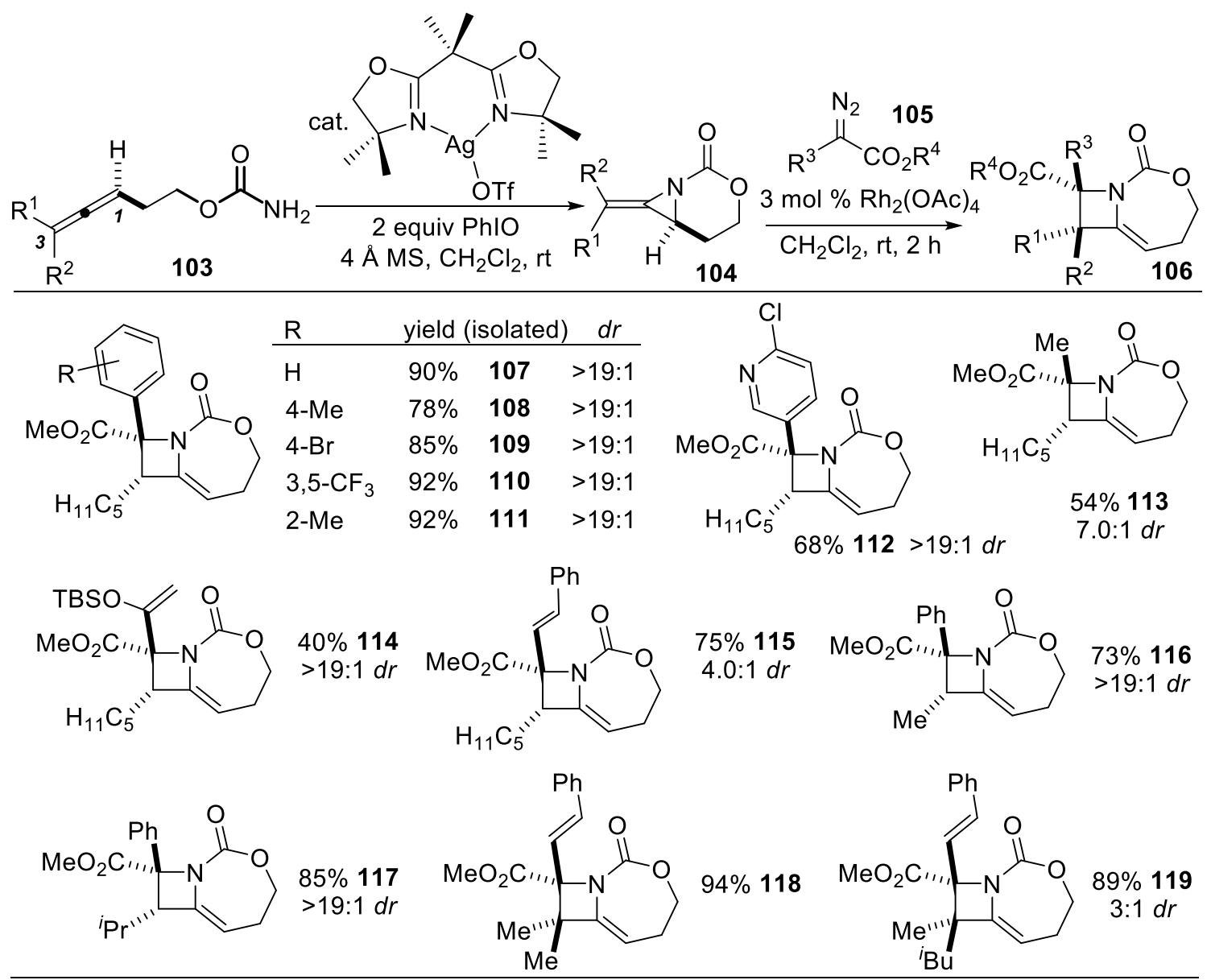

Standard conditions: Slow addition of the diazoester (1.3 equiv) to aziridine (1.0 equiv) over $2 \mathrm{~h}$.

Scheme 14. Rh-catalyzed one-carbon ring expansions of carbamoyl-derived methyleneaziridines.

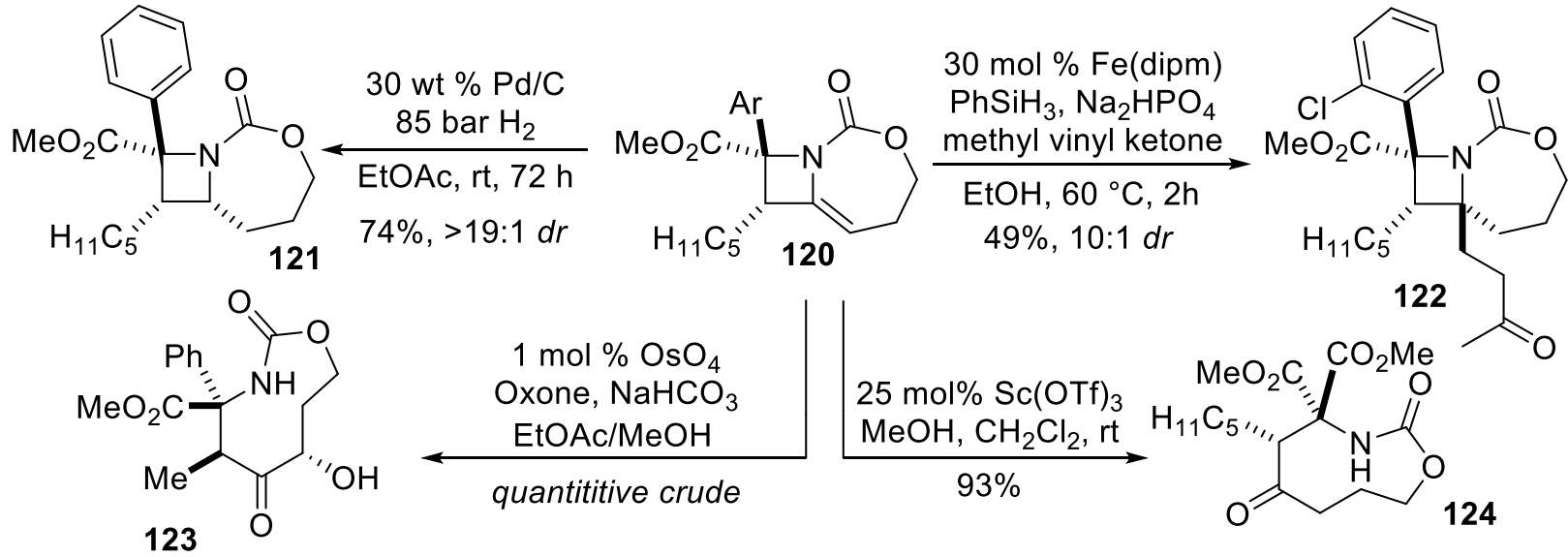

Scheme 15. Further transformations of bicyclic methyleneazetidines.

Methyleneazetidine 120 was further functionalized via hydrogenation to give azetidine 121 in high $d r$ (Scheme 15). Baran's iron-catalyzed C-C coupling successfully delivered 122 in good $d r$ to forge a second quaternary stereocenter on the azetidine. ${ }^{85}$ Attempts to oxidatively cleave the alkene to give the $\beta$-lactam were unsuccessful, due to the tendency of the $\mathbf{1 2 0}$ to undergo ring-opening to furnish the interesting macrocycles 123-124 in good yield and $d r$. 
Mechanistic studies of this unusual Rh-catalyzed aziridine ring expansion showed that the chirality was transferred from the enantioenriched MA $(S)$-125 to the azetidine $(S, S)$-129 with excellent fidelity (Scheme 16). ${ }^{84}$ Experimental and computational studies support the formation of an initial aziridinium ylide 127 via attack of the nitrogen on the Rh-bound carbene. Loss of Rh to 128 , followed by concerted $[2,3]$-Stevens rearrangement furnishes the azetidine product $(S, S)-\mathbf{1 2 9} .^{84,86}$

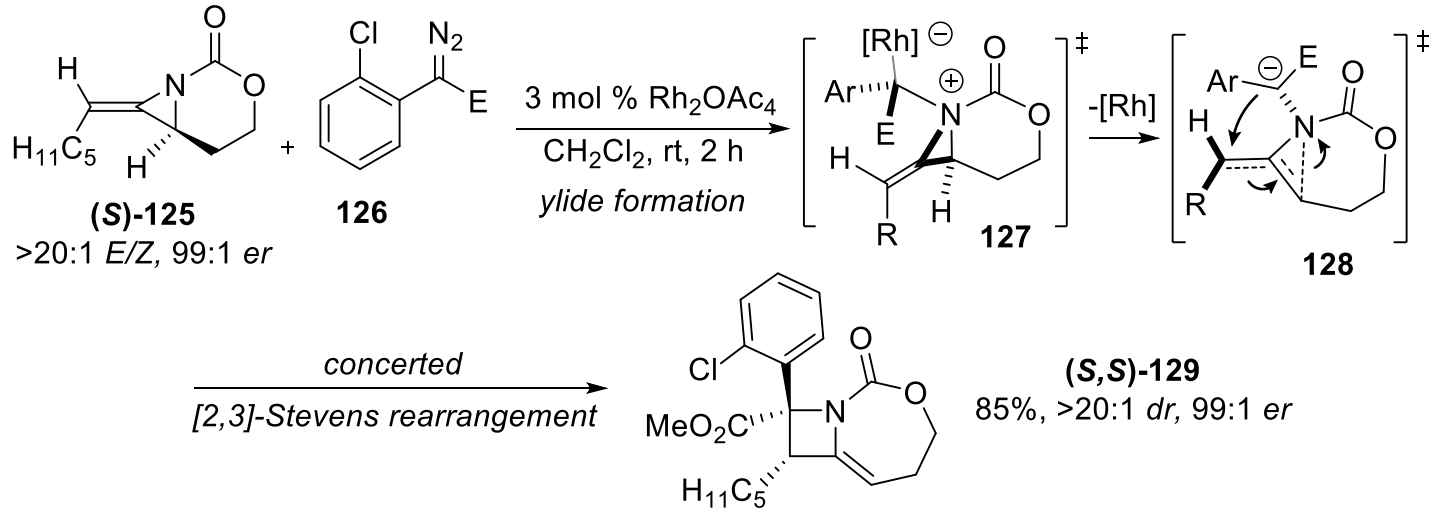

Scheme 16. Mechanistic insight into Rh-catalyzed [3+1] ring expansions of Mas.

\subsection{Formation and trapping of 2-amidoallyl cation intermediates}

In contrast to the chemistry of 2-oxaallyl cations, their 2-azaallyl cation counterparts have received much less attention, due to the limited methods available to generate these reactive species cleanly. ${ }^{87-91}$ Allene aziridination of $\mathbf{1 3 0}$ to $\mathbf{1 3 1}$ (Scheme 17) offers a stereodivergent approach to the synthesis of cycloheptenes of the form 134. The general strategy involves the use of different reaction conditions to control the geometry of the 2-amidoallyl cation 132.92 In this manner, the stereochemistry of the subsequent [4+3] cycloaddition with furan to furnish 133 could be altered in a tunable manner. ${ }^{93}$ Likewise, reagent-controlled reduction in the transformation of $\mathbf{1 3 3}$ to $\mathbf{1 3 4}$ provides an opportunity to vary the relative stereochemistry between the amine at C2 and the stereochemistry at C1 and C3 of the original allene precursor. In this manner, stereodivergent syntheses of four different stereoisomers of $\mathbf{1 3 4}$ from a single allene might be accomplished.
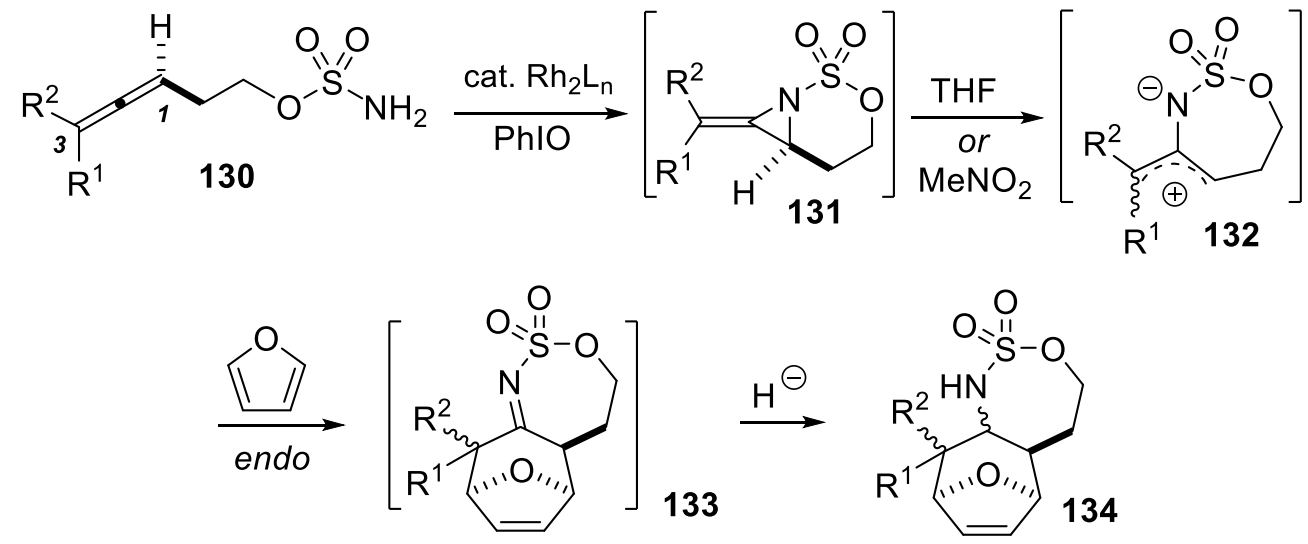

Scheme 17. General strategy for stereodivergent transformations of allenes to carbocycles.

Stereodivergent [4+3] reactions were initiated by treating allene 135 with catalytic $\mathrm{Rh}_{2} \mathrm{TPA}_{4}$ to generate 136 in situ. Addition of a 1:1 mixture of furan/THF furnished the 1,3-syn heterocycle 139 through the intermediacy 
of 137 , whereas a 1:1 furan/ $\mathrm{MeNO}_{2}$ mixture delivered the 1,3-anti heterocycle 142 via $138 .{ }^{93}$ Further stereodivergence was accomplished in reagent-controlled reduction of the imines of 139 and 142 . Small hydrides, such as $\mathrm{NaBH}_{3} \mathrm{CN}$, favored approach of the nucleophile from the top face of 139 to furnish 141, while reaction of 142 provided 144. A bulky LiBHEt$_{3}$ reductant with 139 favored 140, provided $R^{2}$ was $H$. Unfortunately, the use of $\mathrm{LiBHEt}_{3}$ with 142 did not deliver 143 in good $d r$, and $\mathrm{AlH}_{3} \mathrm{Me}_{2} \mathrm{NEt}$ was required to yield the final diastereomer 143, albeit with limited scope. The reaction sequence could be accomplished in one pot, with moderate yields over the three steps (Scheme 18, bottom for one example) and moderate-to-excellent $d r$. As expected, formation of the achiral 2-amidoallyl cation precluded effective transfer of axial-to-point chirality; however, an external asymmetric center was able to control the diastereoselectivity of the [4+3] reaction to yield product in $97 \%$ ee (not shown). ${ }^{93}$

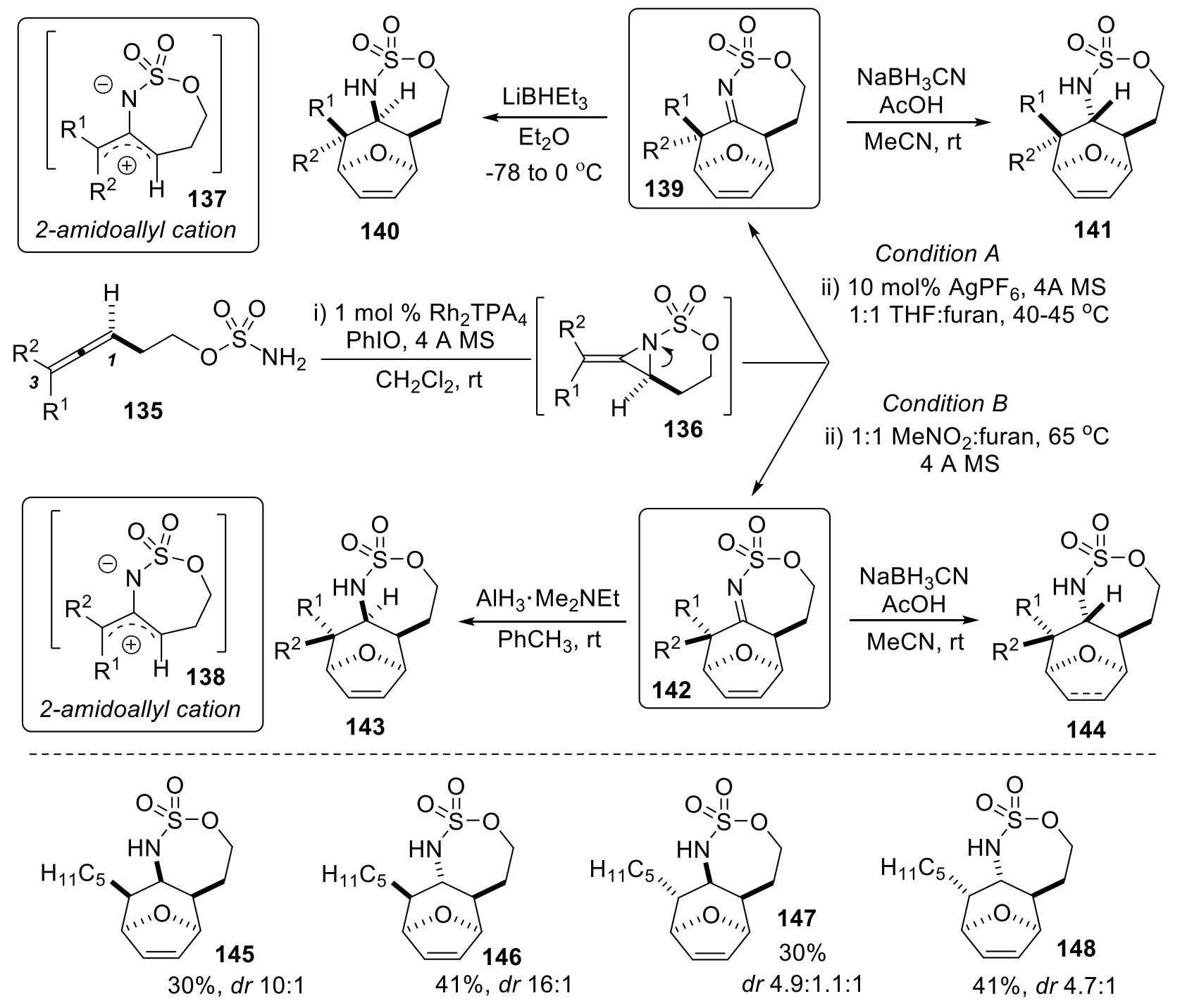

Scheme 18. Stereodivergent, [4+3] cycloadditions of furan with 2-amidoallyl cations from allenes.

Despite the moderate yields, this one-pot sequence significantly increases the structural complexity of a simple allene to give densely functionalized carbocycles. The products can be manipulated in a number of ways (Scheme 19), including ring-opening to yield 150-151, ring contraction to deliver the pyrrolidine 152, opening of 
the oxygen bridge to furnish 153-154, diastereoselective dihydroxylation to provide a fully substituted cycloheptane 155, and addition of carbon nucleophiles to 149 to give 156.

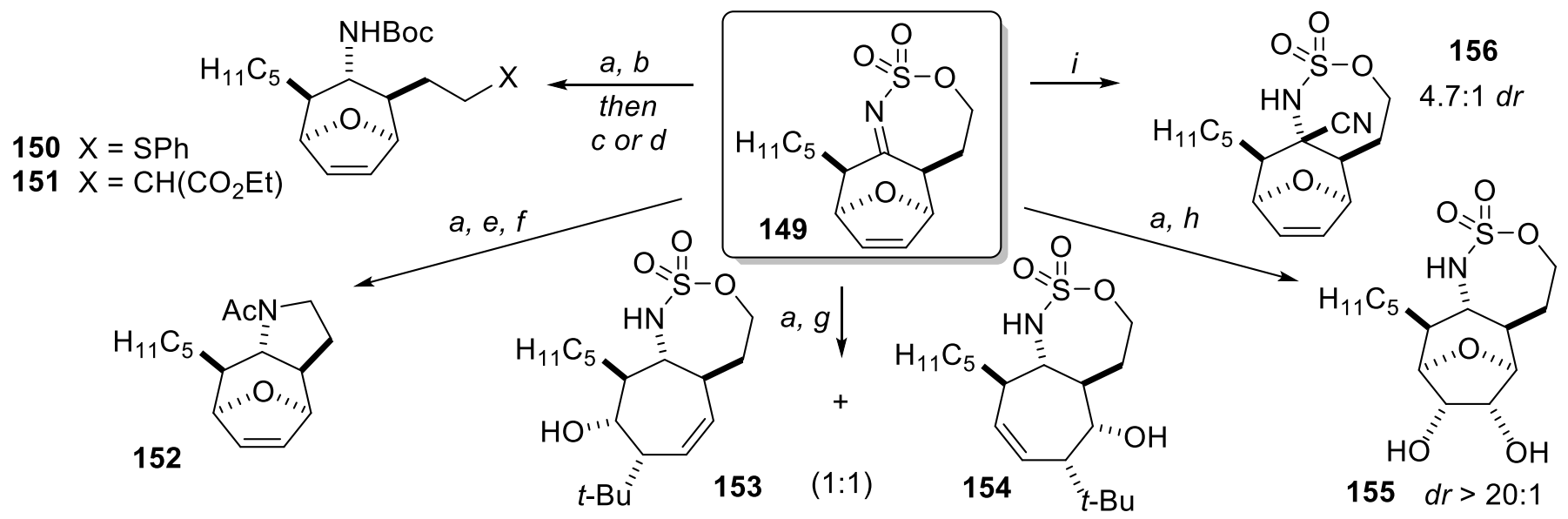

a: $\mathrm{NaBH}_{3} \mathrm{CN}, \mathrm{AcOH}, \mathrm{MeCN} ; 41 \%, 16: 1 d r$ from allene. b: $\mathrm{Boc}_{2} \mathrm{O}$, DMAP, $\mathrm{Et}{ }_{3} \mathrm{~N}, \mathrm{CH}_{2} \mathrm{Cl}_{2}$, rt. c: $\mathrm{PhSH}, \mathrm{K}_{2} \mathrm{CO}_{3}$, $\mathrm{CH}_{3} \mathrm{CN}$, rt; $75 \%$ from 149. d: $\mathrm{CH}_{2}\left(\mathrm{CO}_{2} \mathrm{Et}\right)_{2}, \mathrm{Bu}_{4} \mathrm{NBr}, \mathrm{Cs}_{2} \mathrm{CO}_{3}, \mathrm{MeCN}$, rt; $58 \%$ from 149. e: KOt-Bu, DMAP, $\mathrm{CH}_{2} \mathrm{Cl}_{2}, 0{ }^{\circ} \mathrm{C}$, then $\mathrm{Ac}_{2} \mathrm{O}$, rt; $96 \%$. $f$ : Nal, DMF, $60{ }^{\circ} \mathrm{C}$, then $\mathrm{NaH}, 40-60{ }^{\circ} \mathrm{C} ; 83 \%$. $g: t$-BuLi, THF, $-40{ }^{\circ} \mathrm{C} ; 61 \%, 1: 1$ mix of regioisomers. $\boldsymbol{h}: 10 \mathrm{~mol} \% \mathrm{OsO}_{4}, \mathrm{NMO}$, acetone $/ \mathrm{H}_{2} \mathrm{O}, t-\mathrm{BuOH}, \mathrm{rt} ; 65 \%,>20: 1 d r$. $\boldsymbol{i}: \boldsymbol{n}-\mathrm{Bu}_{4} \mathrm{NCN}, \mathrm{MeCN}, \mathrm{rt}$; $80 \%$ from allene.

Scheme 19. Synthetic utility of cycloheptene products.

\section{Applications to the Synthesis of Complex Molecules}

In addition to developing the utility of allenes for the synthesis of amine triads, we wanted to demonstrate how these methods might be utilized to synthesize complex molecules. Targets include novel aminosugars, unnatural and unique amino acids and aminocyclitol scaffolds.

\subsection{Synthesis of aminosugars}

Aminosugars are present in a host of bioactive compounds, including mono- and polysaccharides, glycolipids, nucleotides, anthracycline antitumor agents, and antibiotics. ${ }^{94-98}$ While aminosugars, such as neuraminic acid and glucosamine, are commonly found in nature, there continues to be a need for versatile strategies to prepare 'designer' aminosugars with specific properties for incorporation into glycoconjugates. The ability to flexibly install three contiguous heteroatom-bearing stereocenters at each unsaturated carbon of an allene, coupled with control over relative stereochemistry and effective axial-to-point chirality transfer, has the potential to deliver useful building blocks for aminosugar libraries.

An example of the strategy employed for aminosugar synthesis from allenes is outlined in Scheme $20 .{ }^{99}$ Enantioenriched allene 157 was easily prepared from D-mannitol; a one-pot aziridination to 158, followed by water ring-opening and alcohol protection furnishes the enesulfamate 159. Treatment of 159 with DMDO and a reductant yielded the 2-amino-1,3-diol motif 161 as a 4.1:1 mixture of easily separable diastereomers. A onepot removal of the sulfamoyl group and cleavage of the resulting olefin via ozonolysis gave a protected derivative of 3-deoxy-3-amino-D-allose 163.

While stereochemical flexibility in this chemistry (Scheme 8) was not thoroughly explored, Amadori-type rearrangement of $\alpha$-hydroxyimine 160 to the $\alpha$-aminoketone 164 (Scheme 20, bottom), followed by reduction 
with $\mathrm{LiBEt}_{3} \mathrm{H}$, gave 165 as the major stereoisomer, which maps onto 3-amino-3-deoxy-D-gulose. ${ }^{99}$ We envisage this strategy could also be engaged to introduce a number of other heteroatoms into amine triads to furnish novel aminosugars.<smiles>CCC1(CC)OCC(C=CC=CCOS(N)(=O)=O)O1</smiles><smiles></smiles>
$>10: 1 d r$ (not isolated)

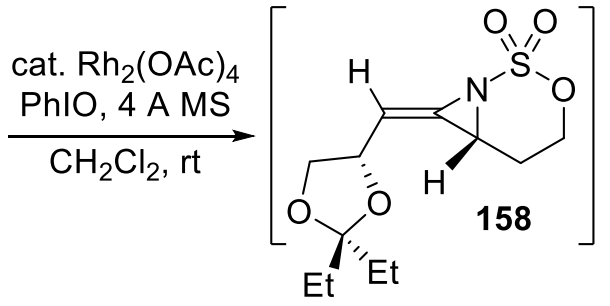

i) $\mathrm{H}_{2} \mathrm{O} / \mathrm{MeCN}$, rt

ii) TBSOTf, 2,6-lutidine $\mathrm{CH}_{2} \mathrm{Cl}_{2},-78{ }^{\circ} \mathrm{C}$ $32 \%$ over 3 steps

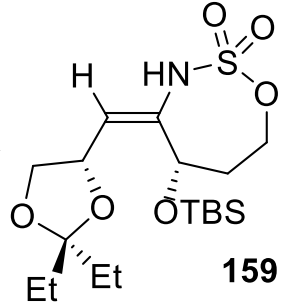

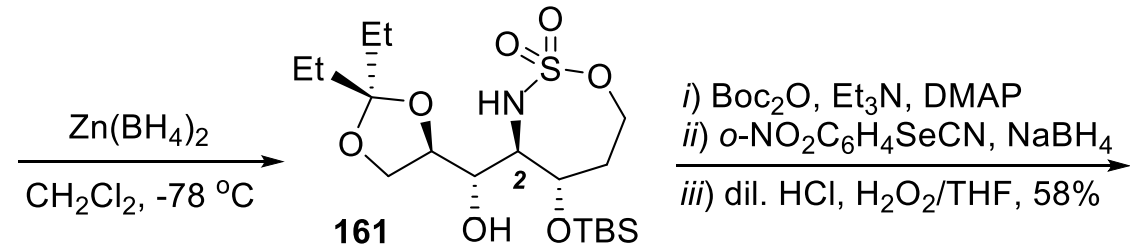

$78 \%, d r 4.1: 1$ at $\mathrm{C} 2$
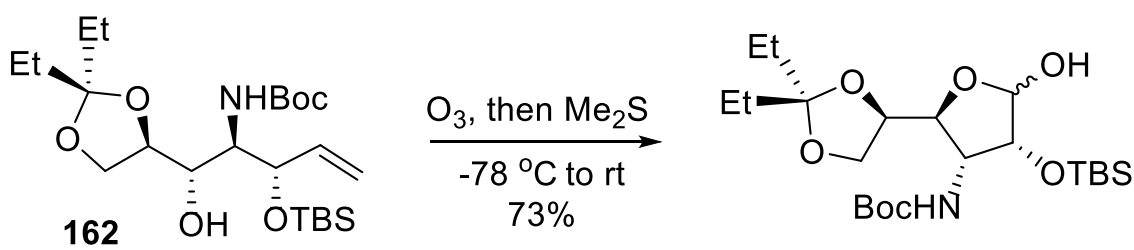

protected 3-deoxy-3-amino-D-allose 163

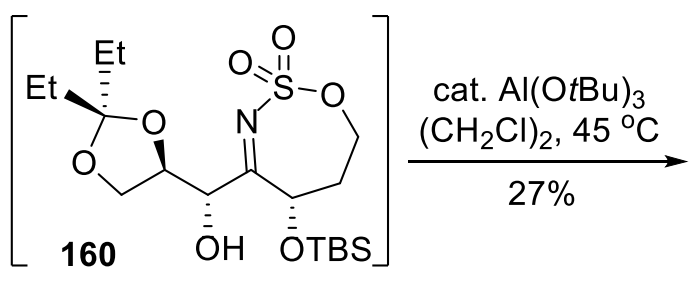<smiles>CCC1(CC)OC[C@@H](C(=O)[C@H]2NS(=O)(=O)OCC[C@H]2O[SbH3])O1</smiles>

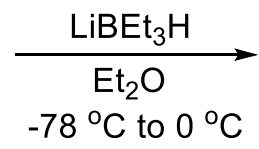

$-78{ }^{\circ} \mathrm{C}$ to $0{ }^{\circ} \mathrm{C}$

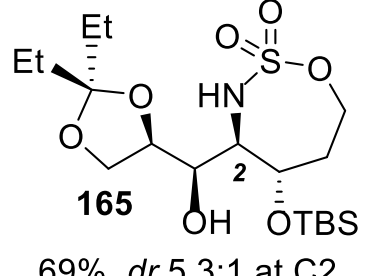

$69 \%, d r 5.3: 1$ at $\mathrm{C} 2$

Scheme 20. Synthesis of aminosugar building blocks via oxidative allene aziridination.

\subsection{Synthesis of unusual and unnatural amino acids, and fluorinated pyrrolidines}

4.2.1. Total synthesis of ( \pm )-detoxinine, its methyl ester, and stereoisomers. Detoxinine is an unusual bishydroxylated $y$-amino acid comprising the core of the detoxifying agent detoxin, a pyrrolidine that is coadministered with blasticidin $\mathrm{S}$ for treating rice blast disease. ${ }^{100-102}$ The stereochemical flexibility of oxidative allene amination, as described in Scheme 8, enables a single homoallenic sulfamate $\mathbf{1 6 6}$ to be transformed to all four possible diastereomers of the methyl ester of detoxinine. A representative O/N/O triad 167 (Scheme 21) was prepared from 166 and transformed into methyldetoxinine. Protection of the free secondary alcohol of the all-syn stereotriad 167 gave 168 in $85 \%$ yield. A Boc group was installed on the amine, followed by a Nal-mediated ring contraction to give intermediate 169 , which was immediately subjected to Tamao-Fleming oxidation to furnish $\mathbf{1 7 0}$ in $67 \%$ yield from 168. A two-step oxidation sequence, followed by an acidic workup, delivered the product ( \pm )-detoxinine methyl ester $\mathbf{1 7 1 .}{ }^{100}$ The same sequence of reactions could be applied to the three remaining diastereomers of $166(\mathbf{1 7 2}, 174$ and $\mathbf{1 7 6}$, Scheme 21, bottom) to give diastereomeric analogues of detoxinine, 173, 175 and 177. 


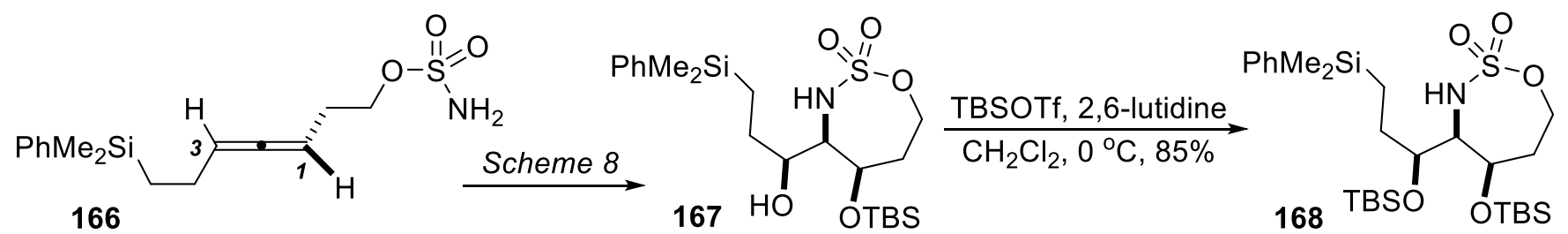
166

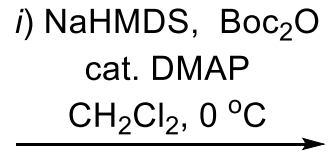

ii) $\mathrm{Nal}, \mathrm{NaH}, \mathrm{DMF}$

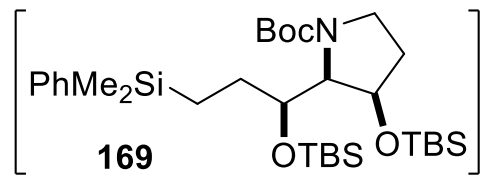

169

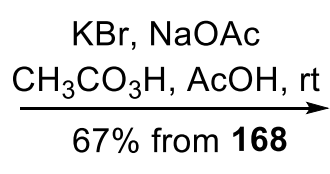

$67 \%$ from 168

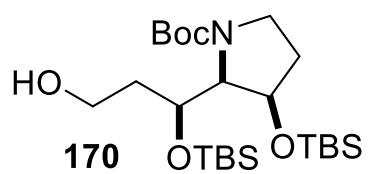

170
( \pm )-detoxinine, methyl ester

171<smiles>[R]C(O)[C@H]1NS(=O)(=O)OC[C@H](CCCC)[C@@H]1[OH2+]</smiles>

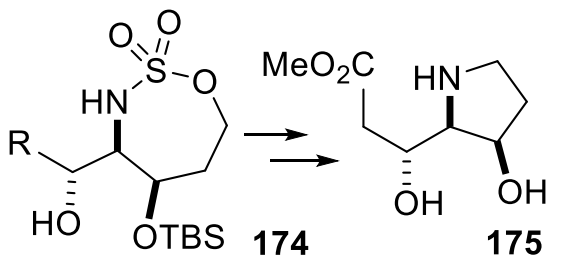

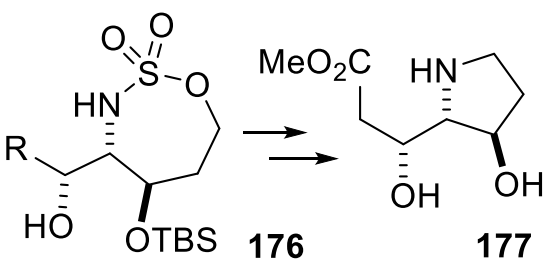

Scheme 21. Total synthesis of ( \pm )-detoxinine methyl ester and stereoisomers.

4.2.2. Fluorinated pyrrolidines and unnatural amino acids. Our ability to introduce fluorine into amine triads (Scheme 7, vide supra) was applied to the synthesis of fluorinated pyrrolidines found in powerful glucosidase inhibitors, including 2,5-dideoxy-2,5-imino-D-mannitol (DMDP) ${ }^{103-106}$ and inhibitors of purine nucleoside phosphorylase (PNP) (Scheme 22) ${ }^{107-109}$ Oxidative allene amination of 178 gave the triad 179 in moderate $d r$ (Scheme 7, vide supra). The nitrogen was protected with a Boc group and the crude material subjected to a Nalmediated ring contraction and purification to deliver the pyrrolidine product 180 in good yield and a $d r>19: 1$.

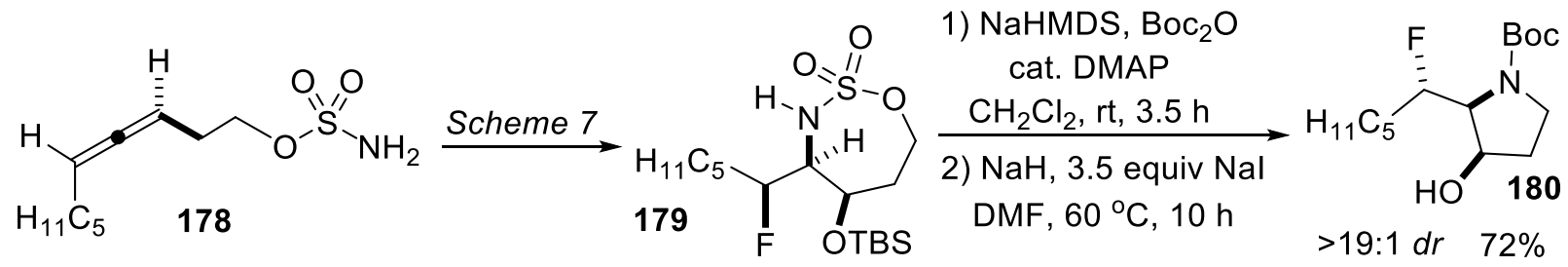

Scheme 22. Synthesis of a fluorinated pyrrolidine scaffold through ring contraction.

Unnatural, fluorinated amino acids play key roles in directing protein-protein interactions, are frequently used in the design of hyperstable protein folds, ${ }^{110-114}$ and exhibit antitumor and antimicrobial activities. ${ }^{115-118}$ The fluorinated amine triads 182 and $\mathbf{1 8 4}$ obtained from the allene precursor 181 through the chemistry described in Scheme 7 are readily transformed in a few steps to $\alpha$-, $\beta$ - and $\gamma$-amino acids (Scheme 23). Ozonolysis of 182 , followed by Pinnick oxidation, yields the $\alpha$-amino acid 183 in good yield. Triad 184 served as the substrate for the synthesis of $\beta$-and $\gamma$-amino acids. For example, the preparation of the protected $\beta$-amino acid 186 proceeded through an initial one-pot, three-step elimination of the sulfamate group of 184 to yield 185 . 
Ozonolysis, Pinnick oxidation and esterification furnished 186 . The protected $y$-amino acid 188 was obtained through the same intermediate 185 via a sequence involving hydroboration and $\mathrm{RuCl}_{3}$-catalyzed oxidation of the alcohol to the carboxylic acid. The ability to transfer axial-to-point chirality from 181 to the amino acid products $183, \mathbf{1 8 6}$, and 188 enables access to either enantiomer of these scaffolds.

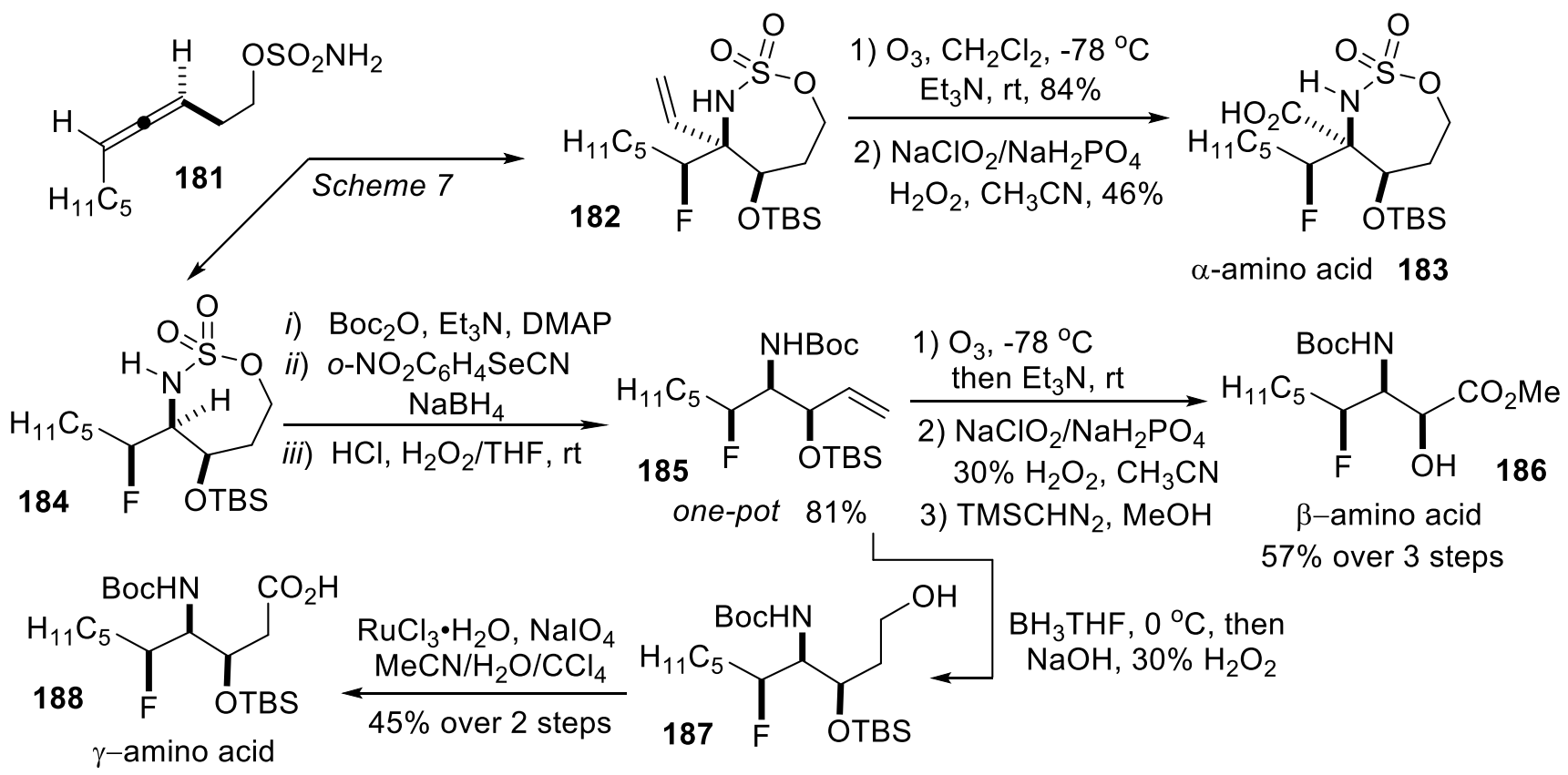

Scheme 23. Transformations of fluorinated amine triads to unnatural amino acids.

\subsection{Synthesis of the core of jogyamycin}

The aminocyclopentitol core of jogyamycin. The natural product jogyamycin was isolated in 2012 from a culture broth of Streptomyces sp. a-WM-JG-16.2 (Figure 2). ${ }^{152}$ The molecule is a complex aminocyclopentitol, where each of the carbons in the core cyclopentane ring is functionalized with a stereodefined hydroxyl or amino group. Jogyamycin is a member of a small class of other natural products that display similar substitution patterns, including pactamycin, de-6-MSA-pactamycin and TM-026. ${ }^{120-126}$ Jogyamycin exhibits potent antiprotozoal activity against organisms that cause malaria and African sleeping sickness, while pactamycin and its analogs have been reported to display anticancer, antiviral and antimicrobial activities, in addition to antiprotozoal activities. ${ }^{119}$ A co-crystal structure of pactamycin bound to a Thermus thermophilus 705 ribosome indicate that the binding site is the $30 \mathrm{~S}$ subunit; the molecule is believed to function as a universal inhibitor of translocation in a highly conserved region of the ribosome. ${ }^{127-130}$ Despite the similar binding sites for aminocyclitols in bacterial and mammalian cells, subtle structural changes in the aminocyclitol core can alter the activity of these natural products for reasons that are not yet well-understood. ${ }^{121,122}$

The three contiguous quaternary stereogenic carbons of jogyamycin, as well as the dense functionalization around the ring that includes sensitive urea and aniline moieties, have inspired a number of strategies to achieve a total synthesis of this molecule. ${ }^{131-142}$ However, these efforts have either been unsuccessful or do not allow for deep-seated changes to the core of the molecule, rendering any future explorations of structure-activity relationships challenging. 


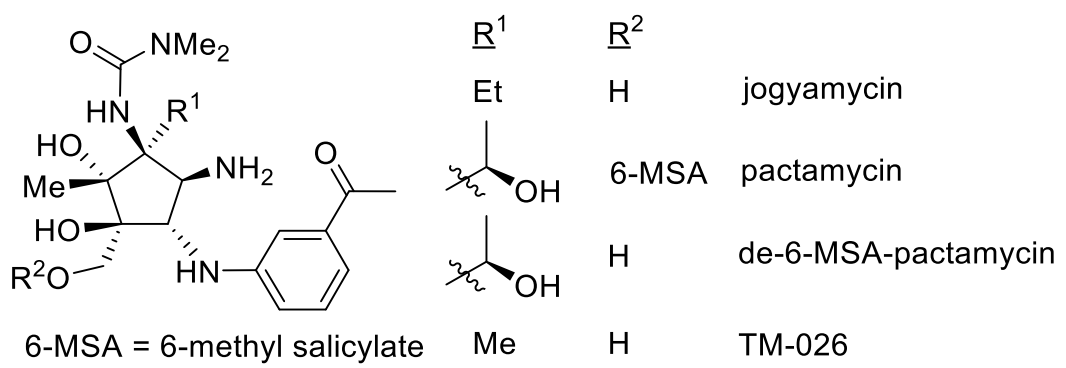

Figure 2. Aminocyclopentitol-containing bioactive natural products.

In order to investigate the impact of targeted changes to the core of jogyamycin on biological activity, we have applied oxidative allene amination to the synthesis of analogues of this natural product (Scheme 24). ${ }^{143} \mathrm{~A}$ three-step, one-pot conversion of allene 189 to 191 was followed by another three-step, one-pot sequence to transform the enesulfamate 191 to the triad 192 in a $d r$ of 11.5:1, which increased to >20:1 after purification. $\mathrm{N}$-Boc protection of 192 furnished 193; ring-opening of the sulfamate with a thiophenol nucleophile to 194 was followed by a one-pot, three-step sequence to install the alkene of 195 in a yield of 68\% over the three steps. Chelation-controlled addition of isopropenylMgBr to 195 gave the amine triad 196 in >20:1 dr.

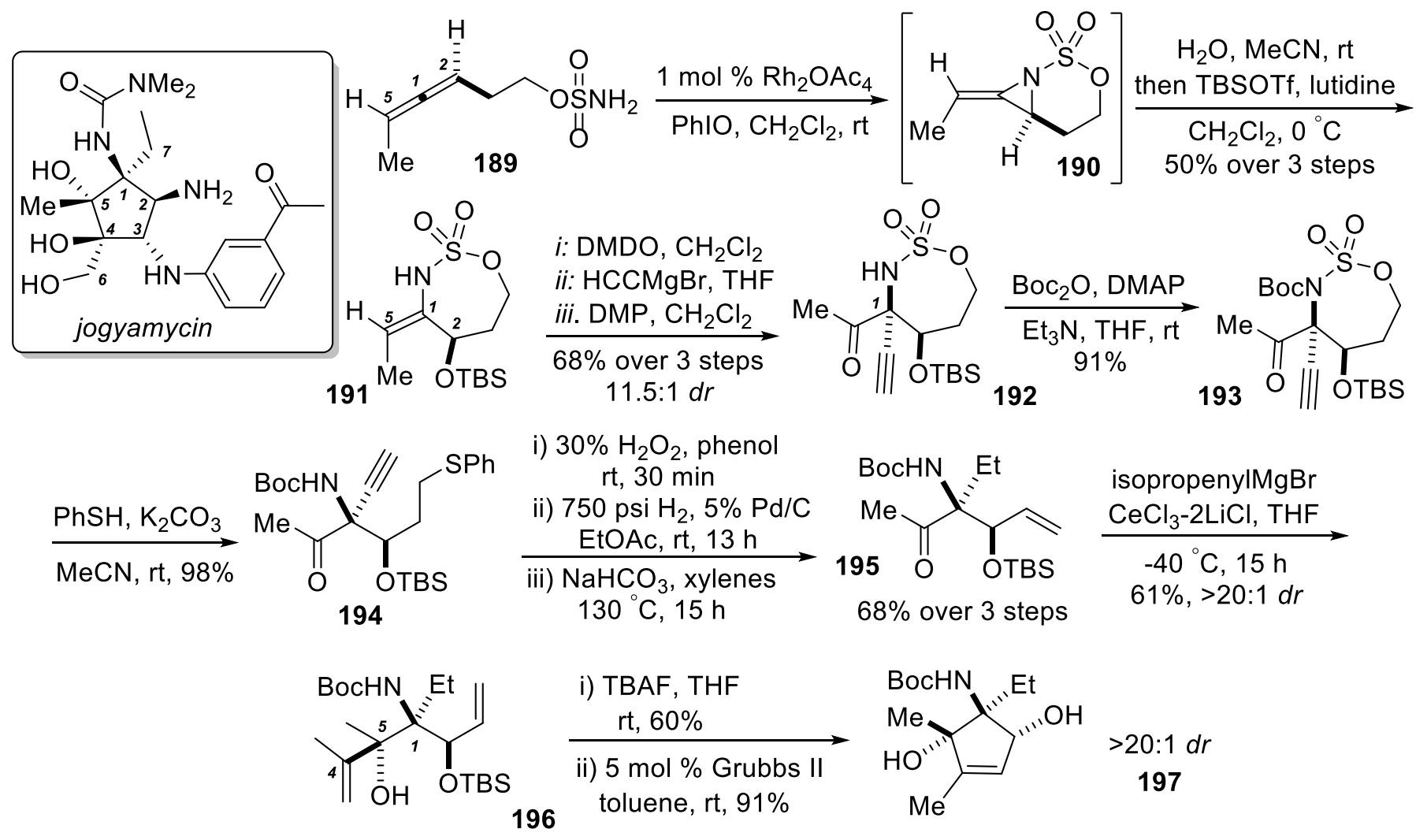

Scheme 24. Synthesis of the core of jogyamycin via oxidative allene amination.

Removal of the TBS protecting group from the secondary alcohol of 196 was required for successful ringclosing metathesis using Grubbs II catalyst to deliver cyclopentene 197 in 91\% yield and >20:1 dr. In addition to accessing the core of jogyamycin, this approach offers flexibility in terms of the introduction of other heteroatoms into the cyclopentane core. 


\section{Concluding Remarks}

Transition metal-catalyzed allene amination methods complement those of conventional alkene oxidation for the synthesis of complex amine-containing stereotriads. A chemo-, regio-, and stereo-selective allene aziridination reaction furnishes key bicyclic methyleneaziridines (MA) that can be manipulated in diverse ways. Ring-opening of the $s p^{3}$ aziridine carbon of the MA initiates a one-pot sequence to deliver C- $\mathrm{X}^{1} / \mathrm{C}-\mathrm{N} / \mathrm{C}-\mathrm{X}^{2}$ triads, where the identities of the two flanking heteroatoms can be readily varied. This strategy was applied to the syntheses of aminosugars, detoxinine and its stereoisomers, fluorinated pyrrolidines, unnatural $\alpha$-, $\beta$ - and $\nu^{-}$ aminoacids, and the core of a bioactive aminocyclopentitol, jogyamycin. The axial chirality of the allene offers the ability to achieve stereodivergence in the resulting triad products, as also enables axial-to-point chirality transfer in many cases.

In contrast to the direct nucleophilic ring-opening of MAs, diastereoselective dihydroxylations and aminohydroxylations on the exocyclic double bond of MAs furnished aminodiols and diaminoalcohols. Ring expansion of MAs to heterocycles, including azetidin-3-ones, methyleneazetidines, and unique sulfamoylcontaining cyclooctynes were reported. Finally, treatment of MAs with heat or Lewis acid generates 2-amidoallyl cations that could be trapped with furan in a stereodivergent manner to deliver aminated cycloheptene scaffolds were described.

Remaining synthetic challenges include the development of selective, intermolecular allene aminations, transition metal-catalyzed strategies to convert racemic allenes to enantioenriched triads, and converting each unsaturated carbon of the allene to a new $s p^{3} \mathrm{C}-\mathrm{C}$ bond.

\section{Acknowledgements}

The author is grateful to all of the students involved in this research over the years, as well as the NSF-CAREER 1254397 and the NIH R01 GM11412, for generous support of our research program.

\section{References}

1. Pasco, M.; Moumne, R.; Lecourt, T.; Micouin, L. J. Org. Chem. 2011, 76, 5137. https://doi.org/10.1021/jo2001512

2. King, S. B.; Ganem, B. J. Am. Chem. Soc. 1994, 116, 562. https://doi.org/10.1021/ja00081a017

3. Zhang, Y.; Liu, S.; Che, Y.; Liu, X. J. Nat. Prod. 2007, 70, 1522. https://doi.org/10.1021/np070239u

4. Ghosh, A. K.; Dawson, Z. L.; Mitsuya, H. Bioorg. Med. Chem. 2007, 15, 7576. https://doi.org/10.1016/i.bmc.2007.09.010

5. Prakesch, M.; Denisov, A. Y.; Naim, M.; Gehring, K.; Arya, P. Bioorg. Med. Chem. 2008, 16, 7443. https://doi.org/10.1016/i.bmc.2008.06.023

6. Hanessian, S.; Soma, U.; Dorich, S.; Deschenes-Simard, B. Org. Lett. 2011, 13, 1048. https://doi.org/10.1021/ol103094j 
7. Beaulieu, P.L.; Abraham, P. L.; Anderson, P. C.; Boucher, C.; Bousquet, Y.; Duceppe, J. S.; Gillard, J.; Gorys, V.; Grand-Maitre, C.; Grenier, L.; Guindon, Y.; Guse, I.; Plamondon, L.; Soucy, F.; Valois, S.; Wernic, D.; Yoakim, C. J. Org. Chem. 1997, 62, 3440.

8. Shinada, T.; Ikebe, E.; Oe, K.; Namba, K.; Kawasaki, M.; Ohfune, Y. Org. Lett. 2010, 12, 2170. https://doi.org/10.1021/ol1006339

9. Aminoglycoside Antibiotics; Arya, D. P. Ed.; John Wiley \& Sons: Hoboken, NJ, 2007. https://doi.org/10.1002/9780470149676

10. He, H.; Williamson, R. T.; Shen, B.; Graziani, E. I.; Yang, H. Y.; Sakya, S. M.; Petersen, P. J.; Carter, G. T. J. Am. Chem. Soc. 2002, 124, 9729.

https://doi.org/10.1021/ja020257s

11. Gan, M.; Zheng, X.; Gan, L.; Guan, Y.; Hao, X.; Liu, Y.; Si, S.; Zhang, Y.; Yu, L.; Xiao, C. J. Nat. Prod. 2011, 74, 1142.

https://doi.org/10.1021/np2000733

12. Magano, J. Chem. Rev. 2009, 109, 4398.

https://doi.org/10.1021/cr800449m

13. Kobayashi, J.; Kanda, F.; Ishibashi, M.; Shigemori, H. J. Org. Chem. 1991, 56, 4574. https://doi.org/10.1021/jo00014a052

14. Chang, H.-T.; Chen, C.-T.; Kondo, T.; Siuzdak, G.; Sharpless, K. B. Angew. Chem. Int. Ed. 1996, 35, 451. https://doi.org/10.1002/anie.199601821

15. O'Brien, P. Angew. Chem. Int. Ed. 1999, 38, 326. https://doi.org/10.1002/(SICI)1521-3773(19990201)38:3<326::AID-ANIE326>3.0.CO;2-T

16. Li, G.; Angert, H. H.; Sharpless, K. B. Angew. Chem. Int. Ed. 1996, 35, 2813. https://doi.org/10.1002/anie.199628131

17. Bruncko, M.; Schlingloff, G.; Sharpless, K. B. Angew. Chem. Int. Ed. 1997, 36, 1483. https://doi.org/10.1002/anie.199714831

18. Rudolph, J.; Sennhenn, P. C.; Vlaar, C. P.; Sharpless, K. B. Angew. Chem. Int. Ed. 1996, 35, 2810. https://doi.org/10.1002/anie.199628101

19. Bar, G. L. J.; Lloyd-Jones, G. C.; Booker-Milburn, K. I. J. Am. Chem. Soc. 2005, 127, 7308. https://doi.org/10.1021/ja051181d

20. Muñiz, K.; Streuff, J.; Hövelmann, C. H.; Núñez, A. Angew. Chem. Int. Ed. 2007, 46, 7125. https://doi.org/10.1002/anie.200702160

21. Ingalls, E. L.; Sibbald, P. A.; Kaminsky, W.; Michael F. E. J. Am. Chem. Soc. 2013, 135, 8854. https://doi.org/10.1021/ja4043406

22. Zhang, H.; Pu, W.; Xiong, T.; Li, Y.; Zhou, X.; Sun, K.; Liu, Q.; Zhang, Q. Angew. Chem. Int. Ed. 2013, $52,2529$. https://doi.org/10.1002/anie.201209142

23. Sequeira, F. C., Turnpenny, B. W.; Chemler, S. R. Angew. Chem. 2010, 122, 6509. https://doi.org/10.1002/ange.201003499

24. Sibbald, P. A.; Michael, F. E. Org. Lett. 2009, 11, 1147. https://doi.org/10.1021/ol9000087

25. Aziridines and Epoxides in Organic_Synthesis; Yudin, A. K. Ed.; Wiley-VCH: 2006. https://doi.org/10.1002/3527607862

26. Müller, P.; Fruit, C. Chem. Rev. 2003, 103, 2905. https://doi.org/10.1021/cr020043t

27. Zhu, Y.; Wang, Q.; Cornwall, R. G.; Shi, Y. Chem. Rev. 2014, 114, 8199. 
https://doi.org/10.1021/cr500064w

28. Pellissier, H. Tetrahedron 2010, 66, 1509.

https://doi.org/10.1016/i.tet.2009.11.089

29. Sweeney, J. B. Chem. Soc. Rev. 2002, 31, 247.

https://doi.org/10.1039/B006015L

30. Hu, X. E. Tetrahedron 2004, 60, 2701.

https://doi.org/10.1016/j.tet.2004.01.042

31. Lu, P. Tetrahedron 2010, 66, 2549.

https://doi.org/10.1016/j.tet.2010.01.077

32. Fukuta, Y.; Mita, T.; Fukuda, N.; Kanai, M.; Shibasaki, M. J. Am. Chem. Soc. 2006, 128, 6312. https://doi.org/10.1021/ja061696k

33. Tanner, D. Angew. Chem. Int. Ed. 1994, 33, 599.

https://doi.org/10.1002/anie.199405991

34. Stanković, S.; D'hooghe, M.; Catak, S.; Eum, H.; Waroquier, M.; Speybroeck, V.; De Kimpe, N.; Ha, H. J. Chem. Soc. Rev. 2012, 41, 643.

https://doi.org/10.1039/C1CS15140A

35. Romero, R. M.; Wçste, T. H.; Muçiz, K. Chem. Asian J. 2014, 9, 972.

https://doi.org/10.1002/asia.201301637

36. Jacques, B.; Muñiz, K. In Catalyzed Carbon-Heteroatom Bond Formation; Yudin, A. K. Ed.; Wiley-VCH, 2010.

37. Modern Allene Chemistry, Vol. 1-2 Krause, N.; Hashmi, S. Eds.; Wiley-VCH, 2004. https://doi.org/10.1002/9783527619573

38. Sydnes, L. K. Chem. Rev. 2003, 103, 1133. https://doi.org/10.1021/cr010025w

39. Ogasawara, M. Tetrahedron: Asymm. 2009, 20, 259.

https://doi.org/10.1016/j.tetasy.2008.11.039

40. Allenes in Organic Synthesis Schuster, J.; Coppola, B. Eds.; Wiley, 1984.

41. Leclère, M.; Fallis, A. G. Angew. Chem. Int. Ed. 2008, 47, 568.

https://doi.org/10.1002/anie.200703003

42. Crimmins, M. T.; Emmitte, K. A. J. Am. Chem. Soc. 2001, 123, 1533.

https://doi.org/10.1021/ja005892h

43. Henderson, M. A.; Heathcock, C. H. J. Org. Chem. 1988, 53, 4736. https://doi.org/10.1021/jo00255a014

44. Myers, A. G.; Zheng, B. J. Am. Chem. Soc. 1996, 118, 4492. https://doi.org/10.1021/ja960443w

45. Ogasawara, M. Tetrahedron-Asymm. 2009, 20, 259. https://doi.org/10.1016/j.tetasy.2008.11.039

46. Kim, H.; Williams, L. J. Curr. Opin. Drug Disc. 2008, 11, 870.

47. Ma, S. M. Pure Appl. Chem. 2006, 78, 197. https://doi.org/10.1351/pac200678020197

48. Krause, N.; Hoffmann-Röder, A. Tetrahedron 2004, 60, 11671. https://doi.org/10.1016/j.tet.2004.09.094

49. Brawn, R. A.; Panek, J.S. Org. Lett. 2009, 11, 4362. https://doi.org/10.1021/ol901692n 
50. Zhang, Y.; Cusick, J. R.; Ghosh, P.; Shangguan, N.; Katukojvala, S.; Inghrim, J.; Emge, T. J.; Williams, L. J. J. Org. Chem. 2009, 74, 7707. https://doi.org/10.1021/jo901320f

51. Adams, C. S.; Weatherly, C. D.; Burke, E. G.; Schomaker, J. M. Chem. Soc. Rev. 2014, 43, 3136. https://doi.org/10.1039/C3CS60416K

52. Bingham, E. M.; Gilbert, J. C. J. Org. Chem. 1975, 40, 224. https://doi.org/10.1021/jo00890a016

53. Atkinson, R. S.; Malpass, J. R. Tetrahedron Lett. 1975, 16, 4305. https://doi.org/10.1016/S0040-4039(00)91179-1

54. Adams, C. S.; Boralsky, L. A.; Guzei, I. A.; Schomaker, J. M. J. Am. Chem. Soc. 2012, 134, 10807. https://doi.org/10.1021/ja304859w

55. Robertson, J.; Feast, G. C.; White, L. V.; Steadman, V. A.; Claridge, T. D. W. Org. Biomol. Chem. 2010, 8, 3060.

https://doi.org/10.1039/c003693e

56. Zhurakovskyi, O.; Ellis, S. R.; Thompson, A. L.; Robertson, J. Org. Lett. 2017, 19, 2174. https://doi.org/10.1021/acs.orglett.7b00834

57. Burke, E. G.; Schomaker, J. M. Angew. Chem. Int. Ed. 2015, 54, 12097. https://doi.org/10.1002/anie.201504723

58. Rigoli, J. W.; Boralsky, L. A.; Hershberger, J. C.; Meis, A. R.; Guzei, I. A.; Schomaker, J. M. J. Org. Chem. 2012, $77,2446$. https://doi.org/10.1021/jo3000282

59. Boralsky, L. A.; Marston, D.; Grigg, R. D.; Hershberger, J. C.; Schomaker, J. M. Org. Lett. 2011, $13,1924$. https://doi.org/10.1021/ol2002418

60. Rigoli, J. W.; Weatherly, C. D.; Vo, B. T.; Neale, S.; Meis, A. R.; Schomaker, J. M. Org. Lett. 2013, 15, 290. https://doi.org/10.1021/ol303167n

61. Rigoli, J. W.; Weatherly, C. D.; Alderson, J. M.; Vo, B. T.; Schomaker, J. M. J. Am. Chem. Soc. 2013, 135, 17238.

https://doi.org/10.1021/ja406654y

62. Ju, M.; Weatherly, C. D.; Guzei, I. A.; Schomaker, J. M. Angew. Chem. Int. Ed. 2017, 56, 9944. https://doi.org/10.1002/anie.201704786

63. Wang, J.; Sanchez-Rosello, M.; Acena, J. L.; del Pozo, C.; Sorochinsky, A. E.; Fustero, S.; Soloshonok, V. A.; Liu, H. Chem. Rev. 2014, 114, 2432.

https://doi.org/10.1021/cr4002879

64. Vitale, A.; Bongiovanni, R.; Ameduri, B. Chem. Rev. 2015, 115, 8835.

https://doi.org/10.1021/acs.chemrev.5b00120

65. Ilardi, E. A.; Vitaku, E.; Njardarson, J. T. J. Med. Chem. 2014, 57, 2832.

https://doi.org/10.1021/im401375q

66. Purser, S.; Moore, P. R.; Swallow, S.; Gouverneur, V. Chem. Soc. Rev. 2008, 37, 320. https://doi.org/10.1039/B610213C

67. Isanbor, C.; O'Hagan, D. J. Fluorine Chem. 2006, 127, 303. https://doi.org/10.1016/j.jfluchem.2006.01.011

68. O'Hagan, D. Chem. Soc. Rev. 2008, 37, 308.

https://doi.org/10.1039/B711844A

69. Müller, K.; Faeh, C.; Diederich, F. Science 2007, 317, 1881. 
https://doi.org/10.1126/science.1131943

70. Ullrich, T.; Sasmal, S.; Boorgu, V.; Pasagadi, S.; Cheera, S.; Rajagopalan, S.; Bhumireddy, A.; Shashikumar, D.; Chelur, S.; Belliappa, C.; Pandit, C.; Krishnamurthy, N.; Mukherjee, S.; Ramanathan, A.; Ghadiyaram, C.; Ramachandra, M.; Santos, P. G.; Lagu, B.; Bock, M. G.; Perrone, M. H.; Weiler, S.; Keller, H. J. Med. Chem. 2014, 57, 7396.

https://doi.org/10.1021/jm5009049

71. Liu, L.; Gerstner, N. C.; Oxtoby, L. J.; Guzei, I.A.; Schomaker, J. M. Org. Lett. 2017, 19, 3239. https://doi.org/10.1021/acs.orglett.7b01342

72. Banks, R. E.; Mohialdin-Khaffaf, S. N.; Lal, G. S.; Sharif, I.; Syvret, R. G. J. Chem. Soc., Chem. Commun. 1992, 8,595 .

https://doi.org/10.1039/c39920000595

73. Adams, C. S.; Grigg. R. D.; Schomaker, J. M. Chem. Sci. 2014, 5, 3046.

https://doi.org/10.1039/C4SC01214C

74. Rigoli, J. W.; Guzei, I. A.; Schomaker, J. M. Org. Lett. 2014, 16, 1696.

https://doi.org/10.1021/ol5003576

75. Weatherly C. D.; Guzei, I. A.; Schomaker, J. M. Eur. J. Org. Chem. 2013, 3667.

https://doi.org/10.1002/ejoc.201300416

76. Brandi, A.; Cicchi, S.; Cordero, F. M. Chem. Rev. 2008, 108, 3988.

https://doi.org/10.1021/cr800325e

77. Bott, T. M.; West, F. G. Heterocycles 2012, 84, 223.

https://doi.org/10.3987/REV-11-SR(P)9

78. Antermite, D.; Degennaro, L.; Luisi, R. Org. Biomol. Chem. 2017, 15, 34. https://doi.org/10.1039/C6OB01665K

79. Sakamoto, R.; Inada, T.; Sakurai, S.; Maruoka, K. Org. Lett. 2016, 18, 6252. https://doi.org/10.1021/acs.orglett.6b03003

80. Takizawa, S.; Arteaga, F. A.; Yoshida, Y.; Suzuki, M.; Sasai, H. Org. Lett. 2013, 15, 4142. https://doi.org/10.1021/ol401817q

81. Zhang, H.-H.; Luo, Y.-C.; Wang, H.-P.; Chen, W.; Xu, P.-F. Org. Lett. 2014, 16, 4896. https://doi.org/10.1021/ol5024079

82. Han, J.-Q.; Zhang, H.-H.; Xu, P.-F.; Luo, Y.-C. Org. Lett. 2016, 18, 5212. https://doi.org/10.1021/acs.orglett.6b02430

83. Ghosh, A.; Mandal, S.; Chatteraj, P. K.; Banerjee, P. Org. Lett. 2016, 18, 4940. https://doi.org/10.1021/acs.orglett.6b02417

84. Schmid, S. C.; Guzei, I. A.; Schomaker, J. M. Angew. Chem. Int. Ed. 2017, 56, 12229. https://doi.org/10.1002/anie.201705202

85. Lo, J. C.; Kim, D.; Pan, C.-M.; Edwards, J. T.; Yabe, Y.; Gui, J.; Qin, T.; Gutierrez, S.; Giacoboni, J.; Smith, M. W.; Holland, P. L.; Baran, P. S. J. Am. Chem. Soc. 2017, 139, 2484.

https://doi.org/10.1021/jacs.6b13155

86. Schmid, S. C.; Guzei, I. A.; Fernández, I.; Schomaker, J. M. ACS Catal. 2018, 8, 7907. https://doi.org/10.1021/acscatal.8b02206

87. Lohse, A. G.; Hsung, R. P. Chem. Eur. J. 2011, 17, 3812. https://doi.org/10.1002/chem.201100260

88. Harmata, M. Chem. Commun. 2010, 46, 8904. https://doi.org/10.1039/c0cc03621h 
89. Robertson, J.; Feast, G. C.; White, L. V.; Steadman, V. A.; Claridge, T. D. W. Org. Biomol. Chem. 2010, 8, 3060.

https://doi.org/10.1039/c003693e

90. Prie, G.; Prevost, N.; Twin, H.; Fernandes, S. A.; Hayes, J. F.; Shipman, M. Angew. Chem. Int. Edit. 2004, 43, 6517.

https://doi.org/10.1002/anie.200461084

91. Thornton, A. R.; Martin, V. I.; Blakey, S. B. J. Am. Chem. Soc. 2009, 131, 2434.

https://doi.org/10.1021/ja809078d

92. Shimizu, N.; Tanaka, M.; Tsuno, Y. J. Am. Chem. Soc. 1982, 104, 1330.

https://doi.org/10.1021/ja00369a031

93. Gerstner, N. C.; Adams, C. S.; Tretbar, M.; Schomaker, J. M. Angew. Chem. Int. Ed. 2016, 128, 13434. https://doi.org/10.1002/ange.201606195

94. Johnson, D. A.; Liu, H.-W. Curr. Opin. Chem. Biol. 1998, 2, 642.

https://doi.org/10.1016/S1367-5931(98)80096-3

95. Weymouth-Wilson, A. C. Nat. Prod. Rep. 1997, 14, 99.

https://doi.org/10.1039/np9971400099

96. Aminoglycoside Antibiotics; Hooper, I. R. Ed.; Springer-Verlag: New York, 1982.

97. Carbohydrate-Based Drug Discovery; Wong, C.-H. Ed.; Wiley-VCH Verlag GmbH \& C. KGaA: Weinheim, 2003.

98. Preparative Carbohydrate Chemistry; Hanessian, S. Ed.; Marcel Dekker: New York, 1997.

99. Adams, C. S.; Grigg. R. D.; Schomaker, J. M. Tetrahedron 2014, 70, 4128.

https://doi.org/10.1016/j.tet.2014.03.084

100. Joullié, M. M.; Li, W.-R.; Han, S.-Y. Heterocycles 1993, 36, 359.

https://doi.org/10.3987/REV-92-453

101. Yonehara, H.; Seto, H.; Aizawa, S.; Hidaka, T.; Shimazu, A.; Otake, N. J. Antibiot. 1968, 21, 369. https://doi.org/10.7164/antibiotics.21.369

102. Yonehara, H.; Seto, H.; Shimazu, A.; Aizawa, S.; Hidaka, T.; Kakinuma, K.; Otake, N. Agricul. Biol. Chem. 1973, 37, 2771.

https://doi.org/10.1271/bbb1961.37.2771

103. Legler, G. Adv. Carbohydr. Chem. Biochem. 1990, 48, 319.

https://doi.org/10.1016/S0065-2318(08)60034-7

104. Wrodnigg, T. Monatsh. Chem. 2002, 133, 393.

https://doi.org/10.1007/s007060200018

105. Andersen, S. M.; Ebner, M.; Ekhart, C. W.; Gradnig, G.; Legler, G.; Lundt, I.; Stütz, A. E.; Withers, S. G.; Wrodnigg, T. Carbohydr. Res. 1997, 301, 155.

https://doi.org/10.1016/S0008-6215(97)00099-2

106. Wrodnigg, T. M.; Diness, F.; Gruber, C.; Häusler, H.; Lundt, I.; Rupitz, K.; Steiner, A. J.; Stütz, A. E.; Tarling, C. A.; Withers, S. G.; Wölfler, H. Bioorg. Med. Chem. 2004, 12, 3485.

https://doi.org/10.1016/i.bmc.2004.04.037

107. Krenitsky, T. A. Mol. Pharmacol. 1967, 3, 526.

108. Mason, J. M.; Murkin, A. S.; Li, L.; Schramm, V. L.; Gainsford, G. J.; Skelton, B. W. J. Med. Chem. 2008, 51, 5880.

https://doi.org/10.1021/jm800792b

109. Evans, G. B.; Furneaux, R. H.; Lewandowicz, A.; Schramm, V. L.; Tyler, P. C. J. Med. Chem. 2003, 46, 3412. 
https://doi.org/10.1021/jm030145r

110. Yoder, N. C.; Kumar, K. Chem. Soc. Rev. 2002, 31, 335.

https://doi.org/10.1039/b201097f

111. Odar, C.; Winkler, M.; Wiltschi, B. Biotechnol. J. 2015, 10, 427.

https://doi.org/10.1002/biot.201400587

112. Wang, P.; Tang, Y.; Tirrell, D. A. J. Am. Chem. Soc. 2003, 125, 6900.

https://doi.org/10.1021/ja0298287

113. Niemz, A.; Tirrell, D. A. J. Am. Chem. Soc. 2001, 123, 7407.

https://doi.org/10.1021/ja004351p

114. Bilgiçer, B.; Fichera, A.; Kumar, K. J. Am. Chem. Soc. 2001, 123, 4393.

https://doi.org/10.1021/ja002961j

115. Gottler, L. M.; Lee, H.-Y.; Shelburne, C. E.; Ramamoorthy, A.; Marsh, E. N. G. Chem. Bio. Chem. 2008, 9, 370.

https://doi.org/10.1002/cbic.200700643

116. Meng, H.; Kumar, K. J. Am. Chem. Soc. 2007, 129, 15615.

https://doi.org/10.1021/ja075373f

117. Tsushima, T.; Kawada, K.; Ishihara, S.; Uchida, N.; Shiratori, O.; Higaki, J.; Hirata, M. Tetrahedron 1988, 44, 5375.

https://doi.org/10.1016/S0040-4020(01)86044-0

118. Tsushima, T.; Kawada, K. Tetrahedron Lett. 1985, 26, 2445.

https://doi.org/10.1016/S0040-4039(00)94849-4

119. Iwatsuki, M.; Nishihara-Tsukashima, A.; Ishiyama, A.; Namatame, M.; Watanabe, Y.; Handasah, S.; Pranamuda, H.; Marwoto, B.; Matsumoto, A.; Takahashi, Y.; Otoguro, K.; Ōmura, S. J. Antibiot. 2012, 65, 169.

https://doi.org/10.1038/ja.2011.136

120. White, F. R. Cancer Chemother. Rep. 1962, 24, 75.

121. Ito, T.; Roongsawang, N.; Shirasaka, N.; Lu, W.; Flatt, P. M.; Kasanah, N.; Miranda, C.; Mahmud, T. Chem. Bio. Chem. 2009, 10, 2253.

https://doi.org/10.1002/cbic.200900339

122. Lu, W.; Roongsawang, N.; Mahmud, T. Chem. Biol. 2011, 18, 425.

123. Otoguro, K.; Iwatsuki, M.; Ishiyama, A.; Namatame, M.; Nishihara-Tukashima, A.; Shibahara, S.; Kondo, S.; Yamada, H.; Ōmura, S.; J. Antibiot. 2010, 63, 381.

https://doi.org/10.1038/ja.2010.50

124. Hanessian, S.; Vakiti, R. R.; Chattopadhyay, A. K.; Dorich, S.; Lavallée, C. Bioorg. Med. Chem. 2013, 21, 1775. https://doi.org/10.1016/j.bmc.2013.01.037

125. Sharpe, R. J.; Malinowski, J. T.; Sorana, F.; Luft, J. C.; Bowerman, C. J.; DeSimone, J. M.; Johnson, J. S. Bioorg. Med. Chem. 2015, 23, 1849.

https://doi.org/10.1016/i.bmc.2015.02.022

126. Almabruk, K. H.; Lu, W.; Li, X.; Abugreen, M.; Kelly, J. X.; Mahmud, T. Org. Lett. 2013, 15, 1678. https://doi.org/10.1021/ol4004614

127. Egebjerg, J.; Garrett, R. A. Biochimie. 1991, 73, 1145.

https://doi.org/10.1016/0300-9084(91)90158-W

128. Carter, A. P.; Clemons, W. M.; Brodersen, D. E.; Morgan-Warren, R. J.; Wimberly, B. T.; Ramakrishnan, V. Nature 2000, 407, 340. 
https://doi.org/10.1038/35030019

129. Dinos, G.; Wilson, D. N.; Teraoka, Y.; Szaflarski, W.; Fucini, P.; Kalpaxis, D.; Nierhaus, K. H. Mol. Cell. 2004, $13,113$.

https://doi.org/10.1016/S1097-2765(04)00002-4

130. Tourigny, D. S.; Fernández, I. S.; Kelley, A. C.; Vakiti, R. R.; Chattopadhyay, A. K.; Dorich, S.; Hanessian, S.; Ramakrishnan, V. J. Mol. Biol. 2013, 425, 3907. https://doi.org/10.1016/j.jmb.2013.05.004

131. Hanessian, S.; Vakiti, R. R.; Dorich, S.; Banerjee, S.; Lecomte, F.; DelValle, J. R.; Zhang, J.; Deschênes-Simard, B. Angew. Chem. Int. Ed. 2011, 50, 3497.

https://doi.org/10.1002/anie.201008079

132. Malinowski, J. T.; Sharpe, R. J.; Johnson, J. S. Science 2013, 340, 180.

https://doi.org/10.1126/science.1234756

133. Malinowski, J. T.; McCarver, S. J.; Johnson, J. S. Org. Lett. 2012, 14, 2878.

https://doi.org/10.1021/ol301140c

134. Loertscher, B. M.; Young, P. R.; Evans, P. R.; Castle, S. L. Org. Lett. 2013, 15, 1930.

https://doi.org/10.1021/ol4005799

135. Haussner, T. J.; Looper, R. E. Org. Lett. 2012, 14, 3632.

https://doi.org/10.1021/ol301461e

136. Knapp, S.; Yu, Y. Org. Lett. 2007, 9, 1359.

https://doi.org/10.1021/ol0702472

137. Tsujimoto, T.; Nishikawa, T.; Urabe, D.; Isobe, M. Synlett 2005, 433.

138. Hanessian, S.; Vakiti, R. R.; Dorich, S.; Banerjee, S.; Deschênes-Simard, B. J. Org. Chem. 2012, 77, 9458. https://doi.org/10.1021/jo301638z

139. Goto, A.; Yoshimura, S.; Nakao, Y.; Inai, M.; Asakawa, T.; Egi, M.; Hamashima, Y.; Kondo, M.; Kan, T. Org. Lett. 2017, 19, 3358.

https://doi.org/10.1021/acs.orglett.7b01257

140. Yamaguchi, M.; Hayashi, M.; Hamada, Y.; Nemoto, T. Org. Lett. 2016, 18, 2347.

https://doi.org/10.1021/acs.orglett.6b00761

141. Rodrigues, R.; Lazib, Y.; Maury, J.; Neuville, L.; Leboeuf, D.; Dauban, P.; Darses, B. Org. Chem. Front. 2018, 5, 948.

https://doi.org/10.1039/C7Q000878C

142. Su, J. Y.; Olson, D. E.; Ting, S. I.; Du Bois, J. J. Org. Chem. 2018, 83, 7121.

https://doi.org/10.1021/acs.joc.8b00142

143. Gerstner, N. C.; Adams, C. S.; Grigg, R. D.; Tretbar, M.; Rigoli, J. W.; Schomaker, J. M. Org. Lett. 2016, 18, 284.

https://doi.org/10.1021/acs.orglett.5b03453

\section{Authors' Biographies}




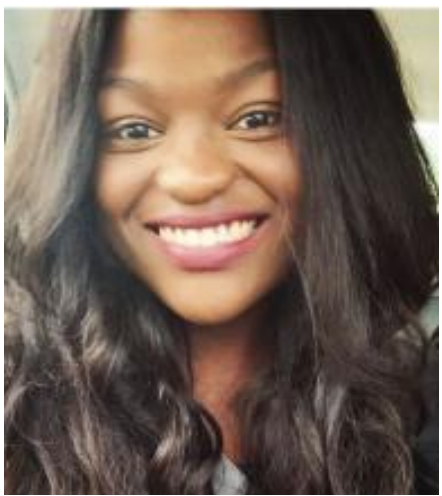

Josephine Eshon was born in Kumasi, Ghana, but moved to Houston, Texas at the age of 10. She graduated from Texas A\&M University in 2015 with a B.S in chemistry and a minor in math, where she studied the mechanism of Friedel-Crafts acylation and $S_{N} 2$ reactions using KIE with Prof. Daniel Singleton. She is currently a graduate student at the University of Wisconsin-Madison with Prof. Clark Landis and Prof. Jennifer Schomaker, studying the hydroformylation of allenes and tandem nitrene-carbene reactions.

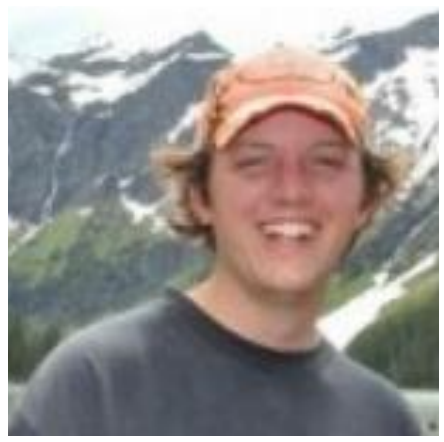

Nels C. Gerstner graduated from Montana State University in 2013 with a B.S. degree in chemistry, where he carried out research under Prof. Trevor Rainey. He is currently a graduate student at the University of WisconsinMadison under Prof. Jennifer Schomaker, where his research has involved transformations of allenes to stereochemically complex amines, as well as efforts towards the total synthesis of jogyamycin and novel analogues.

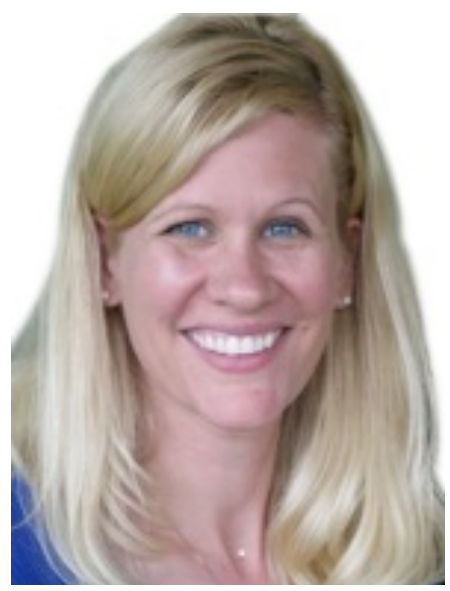

Jennifer M. Schomaker received her Ph.D. degree in 2006 from Michigan State University, working under the supervision of Prof. Babak Borhan. After completing an NIH postdoctoral fellowship at UC-Berkeley under Prof. Robert Bergman and F. Dean Toste, she began her independent career at the University of Wisconsin-Madison 
in 2009. Her research interests include catalyst-controlled $\mathrm{C}-\mathrm{H}$ oxidations, methods for allene functionalizations and the total synthesis of complex bioactive molecules. 